\title{
Bench-to-bedside review: Ventilation-induced renal injury through systemic mediator release - just theory or a causal relationship?
}

\author{
Jan Willem Kuiper ${ }^{1 *}$, Rosanna Vaschetto ${ }^{2,3}$, Francesco Della Corte ${ }^{3}$, Frans B Plöt $z^{\perp}$ and AB Johan Groeneveld²
}

\begin{abstract}
We review the current literature on the molecular mechanisms involved in the pathogenesis of acute kidney injury induced by plasma mediators released by mechanical ventilation. A comprehensive literature search in the PubMed database was performed and articles were identified that showed increased plasma levels of mediators where the increase was solely attributable to mechanical ventilation. A subsequent search revealed articles delineating the potential effects of each mediator on the kidney or kidney cells. Limited research has focused specifically on the relationship between mechanical ventilation and acute kidney injury. Only a limited number of plasma mediators has been implicated in mechanical ventilation-associated acute kidney injury. The number of mediators released during mechanical ventilation is far greater and includes pro- and anti-inflammatory mediators, but also mediators involved in coagulation, fibrinolysis, cell adhesion, apoptosis and cell growth. The potential effects of these mediators is pleiotropic and include effects on inflammation, cell recruitment, adhesion and infiltration, apoptosis and necrosis, vasoactivity, cell proliferation, coagulation and fibrinolysis, transporter regulation, lipid metabolism and cell signaling. Most research has focused on inflammatory and chemotactic mediators. There is a great disparity of knowledge of potential effects on the kidney between different mediators. From a theoretical point of view, the systemic release of several mediators induced by mechanical ventilation may play an important role in the pathophysiology of acute kidney injury. However, evidence supporting a causal relationship is lacking for the studied mediators.
\end{abstract}

*Correspondence: jw.kuiper@vumc.nl

'Department of Pediatric Intensive Care, VUmc Medical Center,

1007 MB Amsterdam, The Netherlands

Full list of author information is available at the end of the article

\section{Introduction}

Acute kidney injury (AKI) is a common problem in critically ill patients and carries significant morbidity and mortality. Based on a recent multinational study, the incidence of AKI is estimated to be $5.7 \%$, with a mortality of $60 \%$ [1]. AKI rarely occurs in isolation but usually develops in the context of multiple organ failure. Despite advances in dialysis technology and supportive care, mortality resulting from AKI has remained unchanged over the past years and is as high as $80 \%$ when associated with respiratory insufficiency [1,2]. An observational study recently found that $75 \%$ of all patients with acute respiratory failure required some form of renal replacement therapy [1].

Mechanical ventilation (MV) is an independent risk factor for the development of AKI and can contribute to its development by three proposed mechanisms: blood gas disturbances leading to hypoxemia or hypercapnia and subsequent neurohumoral-mediated effects on renal blood flow during MV; changes in cardiac output, redistribution of intra-renal blood flow and stimulation of hormonal and sympathetic pathways may affect systemic and renal hemodynamics, thereby decreasing renal blood flow; and MV-induced biotrauma, defined as a pulmonary inflammatory reaction to MV with pulmonary mediator release [1,3]. Subsequent spill-over of these mediators into the systemic circulation may contribute to AKI [4].

Although various processes play significant roles in the pathophysiology of AKI, this review focuses specifically on the potential role of plasma mediators released as a result of MV in the pathogenesis of AKI. First, we review the current clinical and experimental literature describing mediators that are systemically released during MV and their effect on the kidney. The causality of the relationship between systemically released mediators and AKI will be explored. Second, we identify mediators whose release is attributable to MV and discuss the potential effects of these mediators on the kidney. This will provide a framework for future research on ventilation-induced renal injury through systemic mediator release. 


\section{Methods}

We performed an extensive literature search in PubMed using medical subject headings and text words, supplemented by scanning the bibliographies of the recovered articles. We combined 'acute renal failure' and 'acute kidney injury' using the term 'OR'. This search was subsequently combined with 'mechanical ventilation' using the Boolean operator 'AND'. Using a similar search strategy, using 'mediator' and 'cytokine' we identified 19 different plasma mediators that increased during MV. We included only in vivo studies in which the increase in plasma mediator levels was exclusively attributable to MV. We excluded neurohumorally increased mediators, mediators increased in renal tissue samples and mediators derived from in vitro experiments exposing cell cultures to mechanical stretch. Each mediator was searched in PubMed, also including alternative names and abbreviations. We combined these results with the terms 'glomerular', 'glomerulus,' 'tubular', 'mesangial', 'mesangium,' 'podocyte', 'acute renal failure' and 'acute kidney injury'. To delineate the potential effects of these mediators on the kidney, we limited the articles to studies that solely studied effects on the kidney or on different kidney cell types.

\section{Mechanical ventilation, systemic mediator release and the kidney}

The importance of MV in morbidity and mortality of patients suffering from acute respiratory distress syndrome is stressed by the 2000 landmark study by the ARDS Network. In this multi-center trial, lung protective ventilation decreased morbidity and mortality rates compared to a conventional strategy [5]. Although the exact mechanisms remain unknown, the biological response of the lungs to the effects of MV was aptly named biotrauma to describe the ongoing changes in pulmonary inflammation and the systemic release of inflammatory mediators [6]. The biotrauma hypothesis is supported by evidence from experimental models ranging from mechanically stressed cell systems to isolated lungs, intact animals, and humans [7]. Various mechanisms are responsible for the ventilation-induced release of mediators. There are four principal mechanisms, all of which appear to be clinically relevant: stress failure of the plasma membrane (necrosis); stress failure of endothelial and epithelial barriers (decompartmentalization); overdistension without tissue destruction (mechanotransduction); and effects on vasculature, independent of stretch and rupture [8]. The possible effects of systemically released and circulating mediators during ventilator-induced lung injury on organs distant from the lungs has prompted research to focus on the potential effects of mediators on the kidney (Table 1). Thus far only one clinical study has compared a conventional MV strategy with a lung-protective strategy in patients with acute respiratory distress syndrome. This single-center study found increased kidney failure in the conventional strategy group. A correlation was found between plasma IL-6 levels and the number of failing organs in the same patients [9]. In these patients an association between plasma soluble Fas ligand (sFasL) levels and changes in creatinine was also found [10]. The authors conclude that mediator release during MV is correlated to the development of multi-organ failure and these findings may partially explain the decrease in morbidity and mortality in patients ventilated with a lung protective strategy. In animal experiments the role of MV on the kidney was further explored, focusing on the role of pro-inflammatory mediators [11-14], renal apoptosis [10], vasoactive mediators and renal blood flow [15], coagulation and fibrinolysis [16,17], and other mediators such as vascular endothelial growth factor (VEGF) (Table 1) [18]. Of specific importance is the previously mentioned study by Imai and colleagues [10]. In contrast to other animal studies that are observational by nature, this is the only study that used specific blocking of mediators, albeit in vitro. Imai and colleagues found increased renal apoptosis after injurious ventilation in rabbits. In vitro blocking of sFasL prevented induction of apoptosis of cultured kidney cells by plasma from rabbits ventilated with an injurious ventilatory strategy [10]. Although limited in number, studies linking MV with acute respiratory failure have discovered several new potential pathways in addition to pro-inflammatory pathways through which MV may cause acute respiratory failure. To date, however, no study has established a causal relationship between specific mediators and acute respiratory failure during $\mathrm{MV}$ in vivo through, for instance, intervention studies where the release of mediators is prevented or by blocking released mediators.

Table 2 shows the mediators whose increased release was attributable to MV. Several clinical studies identified a large number of plasma mediators [5,19-24]. These plasma mediators are not only pro-inflammatory by nature, but anti-inflammatory mediators have been identified as well [22-24]. Furthermore, identified mediators are also involved in coagulation, fibrinolysis, cell adhesion and surfactant homeostasis [5,19-26]. Most research has focused on pro- and anti-inflammatory mediators as well as chemokines, and only limited studies have outlined a role for mediators primarily involved in cell growth and differentiation or apoptosis (Table 2) $[10,18]$. A more indepth analysis of the various mediators summarized in Table 2 may provide new therapeutic insights.

\section{Potential effects of mediators on the kidney Pro-inflammatory Tumor necrosis factor- $a$}

In 1986 Tracey and colleagues [27] administered TNF- $\alpha$ intravenously to rats and observed, among other things, 
Table 1. Effects of mechanical ventilation on the kidney

\begin{tabular}{|c|c|c|c|c|}
\hline Reference & Model/injury & Ventilation strategy & Plasma mediators & Renal endpoints \\
\hline Ranieri et al. 2000 [9] & ARDS patients & $\begin{array}{l}11 \mathrm{ml} / \mathrm{kg} \text {, PEEP } 6 \text { versus } 8 \mathrm{ml} / \mathrm{kg} \text {, } \\
\text { PEEP } 15\end{array}$ & $\|L-6, T N F-a\| L-,1 \beta, \| L-8$ & Renal failure according to Knaus [198] \\
\hline Choi et al. 2003 [18] & Healthy rats & $20 \mathrm{ml} / \mathrm{kg}$ versus $7 \mathrm{ml} / \mathrm{kg}$ & VEGF & $\begin{array}{l}\text { Proteinuria, albuminuria, eNOS } \\
\text { expression, microvascular leak }\end{array}$ \\
\hline Gurkan et al. 2003 [200] & Acid aspiration in mice & $\begin{array}{l}17 \mathrm{ml} / \mathrm{kg} \text {, PEEP } 3 \text { versus } 6 \mathrm{ml} / \mathrm{kg} \text {, } \\
\text { PEEP } 3\end{array}$ & & IL-6, VEGFR-2 expression \\
\hline Imai et al. 2003 [10] & $\begin{array}{l}\text { Acid aspiration in } \\
\text { rabbits }\end{array}$ & $\begin{array}{l}15 \text { to } 17 \mathrm{ml} / \mathrm{kg} \text {, PEEP } 0 \text { to } 3 \text { versus } \\
5 \text { to } 7 \mathrm{ml} / \mathrm{kg} \text {, PEEP } 9 \text { to } 12\end{array}$ & MCP-1, IL-8, GRO, sFasL & $\begin{array}{l}\text { Creatinine, apoptosis, histological } \\
\text { changes with EM }\end{array}$ \\
\hline Crimi et al. 2006 [11] & $\begin{array}{l}\text { Hemorrhagic shock } \\
\text { and resuscitation in } \\
\text { rats }\end{array}$ & $\begin{array}{l}12 \mathrm{ml} / \mathrm{kg} \text {, PEEP } 0 \text { versus } 6 \mathrm{ml} / \mathrm{kg} \text {, } \\
\text { PEEP } 5\end{array}$ & IL-6, MIP-2 & Creatinine, apoptosis \\
\hline Dhanireddy et al. 2006 [12] & $\begin{array}{l}\text { Bacterial aspiration } \\
\text { (S. aureus) in mice }\end{array}$ & $\begin{array}{l}\text { Spontaneous breathing versus } \\
10 \mathrm{ml} / \mathrm{kg}\end{array}$ & IL-6, KC, MIP-2 & Creatinine \\
\hline O'Mahony et al. 2006 [13] & LPS i.p. in mice & $\begin{array}{l}\text { Spontaneous breathing versus } \\
10 \mathrm{ml} / \mathrm{kg}\end{array}$ & IL-6, KC, MIP-2, TNF-a & Creatinine \\
\hline Kuiper et al. 2008 [15] & Healthy rats & $\begin{array}{l}20 \mathrm{cmH}_{2} \mathrm{O}, \mathrm{PEEP} 2 \text { versus } 14 \mathrm{cmH}_{2} \mathrm{O} \text {, } \\
\text { PEEP } 5\end{array}$ & & $\begin{array}{l}\text { Decreased renal blood flow, increased } \\
\text { renal ET-1 }\end{array}$ \\
\hline Vaschetto et al. 2008 [14] & LPS aspiration in rats & $\begin{array}{l}15 \mathrm{ml} / \mathrm{kg} \text {, PEEP } 0 \text { versus } 6 \mathrm{ml} / \mathrm{kg} \text {, } \\
\text { PEEP } 5\end{array}$ & IL-6, TNF-a & $\begin{array}{l}\text { Kidney apoptosis. Decreased creatinine } \\
\text { clearance }\end{array}$ \\
\hline Hegeman et al. 2009 [201] & Healthy mice & $\begin{array}{l}20 \mathrm{cmH}_{2} \mathrm{O}, \mathrm{PEEP} 0 \text { for } 1,2,4 \text { hours } \\
\text { versus spontaneous breathing }\end{array}$ & & $\begin{array}{l}\text { Increased E-selectin, VCAM-1, ICAM-1, } \\
\text { PECAM-1, IL-1 } \beta \text {, KC mRNA expression. } \\
\text { Increased MPO activity }\end{array}$ \\
\hline Kobr et al. 2009 [26] & Healthy piglets & $\begin{array}{l}10 \mathrm{ml} / \mathrm{kg} \text { versus } 6 \mathrm{ml} / \mathrm{kg} \text { versus } \\
\text { spontaneous breathing }\end{array}$ & VCAM-1, ICAM-1 & $\begin{array}{l}\text { Decreased creatinine clearance and free } \\
\text { water clearance }\end{array}$ \\
\hline
\end{tabular}

ARDS, acute respiratory distress syndrome; EM, electron microscopy; eNOS, endothelial nitric oxide synthase; ET, endothelin; ICAM, intercellular adhesion molecule; i.p., intraperitoneal; LPS, lipopolysaccharide; GRO, growth-regulated oncogene; KC, keratinocyte-derived chemokine; MCP, monocyte chemoattractant protein; MIP, macrophage inflammatory protein; $\mathrm{MPO}$, myeloperoxidase; $\mathrm{PECAM}$, platelet endothelial cell adhesion molecule; $\mathrm{PEEP}$, positive end-expiratory pressure (in cm $\mathrm{H}_{2} \mathrm{O}$ ); sFasL, soluble Fas ligand; VCAM, vascular cell adhesion molecule; VEGF, vascular endothelial growth factor; VEGFR2, vascular endothelial growth factor receptor 2.

hypotension, metabolic acidosis, hemoconcentration, acute tubular necrosis and death. This pleiotropic character of TNF- $\alpha$ is reflected by its multitude of effects on the kidney [28]. TNF- $\alpha$ has been implicated in renal inflammation, inflammatory cell recruitment, adhesion and infiltration, apoptosis and necrosis, vasoconstriction and vasodilatation, alterations in cell morphology and proliferation, coagulation and fibrinolysis, downregulation of urea, glucose, sodium and chloride transporters and renal lipid metabolism and signaling (Table 3). TNF- $\alpha$, through activation of NF- $\kappa B$, induces its own expression by mesangial cells [29-31], podocytes [32-34], and tubular epithelial cells $[35,36]$.

In a TNF- $\alpha$ receptor knock-out mouse model of cisplatin nephrotoxicity and renal tubular epithelial cells, TNF- $\alpha$ increased gene expression of a variety of inflammatory mediators, such as transforming growth factor- $\beta$, RANTES (regulated upon activation, normal T-cell expressed, and secreted), IL- $1 \beta$, TNF- $\alpha$, T-cell activation-3, IL-6 and IL-8 (see Table 3 for a complete list) [37-42]. TNF- $\alpha$ is also capable of increasing expression of major histocompatibility complex (MHC) I on mesangial cells [43], which indicates the stimulation of antigen-presenting properties by mesangial cells under inflammatory circumstances. In vitro exposure of mesangial cells and tubular epithelial cells to TNF- $\alpha$ increased expression of $\mathrm{CC}$ and CXC chemokines (Table 3), which are involved in neutrophil, monocyte and T-lymphocyte recruitment [44-46]. In both tubular epithelial cell monolayer and tubular epithelial and endothelial cell bilayer experiments, TNF- $\alpha$ increased leukocyte transmigration $[41,42]$. By increasing the expression of intercellular adhesion molecule (ICAM)-1, vascular cell adhesion molecule (VCAM)-1 and L-selectin on mesangial cells and glomerular endothelial cells, TNF- $\alpha$ also facilitates leukocyte adhesion and infiltration into the kidney [47-49].

Both in vitro and in vivo studies have shown that TNF$\alpha$ induces caspase 8-dependent apoptosis of renal tubular cells and renal endothelial cells by binding to either the TNF-receptor-1 or Fas-receptor [50-53]. In glomerular endothelial cells, cytochrome c influx in the cytosol was found after TNF- $\alpha$ stimulation, suggesting a role in the mitochondrial pathway as well [54]. Ceramide is an important signaling molecule in cellular responses, including apoptosis [55]. In both mesangial cells and glomerular endothelial cells TNF- $\alpha$ stimulated ceramide formation, but only in the latter did this lead to increased apoptosis [56,57]. TNF- $\alpha$ also suppresses expression of anti-apoptotic proteins, both in vitro and in vivo $[53,54]$. Hruby and colleagues [58] showed in vitro that TNF- $\alpha$ induced cytolysis in mesangial cells, but not in glomerular epithelial cells. This may be partially attributable to the TNF- $\alpha$-induced production of reactive oxygen species by mesangial cells [59]. 
Table 2. Plasma mediator release during mechanical ventilation; patient and animal data

\begin{tabular}{|c|c|c|c|}
\hline Reference & Model/injury & Ventilation strategy & Systemic mediators \\
\hline Calfee et al. [19] & ICU patients & $12 \mathrm{ml} / \mathrm{kg}$ versus $6 \mathrm{ml} / \mathrm{kg}$ & sICAM-1 \\
\hline Eisner et al. [20] & ICU patients & $12 \mathrm{ml} / \mathrm{kg}$ versus $6 \mathrm{ml} / \mathrm{kg}$ & SP-D \\
\hline Parsons et al. [21] & ICU patients & $12 \mathrm{ml} / \mathrm{kg}$ versus $6 \mathrm{ml} / \mathrm{kg}$ & $\| L-6, \mid L-8$ \\
\hline Parsons et al. [22] & ICU patients & $12 \mathrm{ml} / \mathrm{kg}$ versus $6 \mathrm{ml} / \mathrm{kg}$ & sTNFR-1 \\
\hline Ranieri et al. [23] & ARDS patients & $11 \mathrm{ml} / \mathrm{kg}$, PEEP 6 versus $8 \mathrm{ml} / \mathrm{kg}$, PEEP 15 & TNF- $a,\|L-1 \beta\| L-6,, I L-8, \| L-1 R A$, sTNFR-55/75 \\
\hline Stuber et al. [24] & ICU patients & $12 \mathrm{ml} / \mathrm{kg}$, PEEP 5 versus $5 \mathrm{ml} / \mathrm{kg}$, PEEP 15 & IL-6, TNF-a, IL-10, IL-1RA \\
\hline ARDS Network [5] & ICU patients & $12 \mathrm{ml} / \mathrm{kg}$ versus $6 \mathrm{ml} / \mathrm{kg}$ & IL-6 \\
\hline Ware et al. [25] & ICU patients & $12 \mathrm{ml} / \mathrm{kg}$ versus $6 \mathrm{ml} / \mathrm{kg}$ & PAl-1, aPC \\
\hline Chen et al. [17] & Healthy rats & Non-ventilated versus $40 \mathrm{ml} / \mathrm{kg}$ & Active PAl-1 \\
\hline Chiumello et al. [202] & Acid aspiration in rats & $\begin{array}{l}16 \mathrm{ml} / \mathrm{kg} \text { versus } 16 \mathrm{ml} / \mathrm{kg}, 5 \text { PEEP versus } 9 \mathrm{ml} / \mathrm{kg} \\
\text { versus } 9 \mathrm{ml} / \mathrm{kg}, 5 \text { PEEP versus same with } \\
\text { recruitment maneuvers }\end{array}$ & TNF-a, MIP-2 \\
\hline Choi et al. [18] & Healthy rats & $20 \mathrm{ml} / \mathrm{kg}$ versus $7 \mathrm{ml} / \mathrm{kg}$ & VEGF \\
\hline Crimi et al. [11] & $\begin{array}{l}\text { Hemorrhagic shock and } \\
\text { resuscitation in rats }\end{array}$ & $12 \mathrm{ml} / \mathrm{kg}$, PEEP 0 versus $6 \mathrm{ml} / \mathrm{kg}$, PEEP 5 & IL-6, MIP-2 \\
\hline Dhanireddy et al. [12] & S. aureus aspiration in mice & $\mathrm{SB}$ versus $10 \mathrm{ml} / \mathrm{kg}$ & IL-6, KC, MIP-2 \\
\hline Guery et al. [203] & Healthy rats & $30 \mathrm{ml} / \mathrm{kg}$ versus $10 \mathrm{ml} / \mathrm{kg}$ & TNF-a \\
\hline Haitsma et al. [16] & Pneumonia in rats & $12 \mathrm{ml} / \mathrm{kg}$ versus $6 \mathrm{ml} / \mathrm{kg}$, PEEP 5 , versus SB & TATc, active tPA \\
\hline Haitsma et al. [204] & LPS aspiration and i.p. in rats & $45 \mathrm{cmH}_{2} \mathrm{O}$ versus $45 \mathrm{cmH}_{2} \mathrm{O}$, PEEP 10 & TNF-a \\
\hline Haitsma et al. [205] & LPS aspiration and i.p. in rats & $45 \mathrm{cmH}_{2} \mathrm{O}$ versus $45 \mathrm{cmH}_{2} \mathrm{O}$, PEEP 10 & TNF-a \\
\hline Haitsma et al. [206] & Healthy rats & $\begin{array}{l}32 \mathrm{cmH}_{2} \mathrm{O} \text { versus } 32 \mathrm{cmH}_{2} \mathrm{O}, \mathrm{PEEP} 6 \text { versus } \\
13 \mathrm{cmH}_{2} \mathrm{O}, \mathrm{PEEP} 3\end{array}$ & IL-6, MIP-2 \\
\hline Herrera et al. [207] & Septic rats & $\begin{array}{l}20 \mathrm{ml} / \mathrm{kg} \text { versus } 6 \mathrm{ml} / \mathrm{kg} \text { versus } 20 \mathrm{ml} / \mathrm{kg} \text {, PEEP AIP } \\
\text { versus } 6 \mathrm{ml} / \mathrm{kg} \text {, PEEP AIP }\end{array}$ & TNF-a, IL-6 \\
\hline Imai et al. [10] & Acid aspiration in rabbits & $\begin{array}{l}15 \text { to } 17 \mathrm{ml} / \mathrm{kg} \text {, PEEP } 0 \text { to } 3 \text { versus } 5 \text { to } 7 \mathrm{ml} / \mathrm{kg} \text {, } \\
\text { PEEP } 9 \text { to } 12\end{array}$ & MCP-1, IL-8, GRO, sFasL \\
\hline Kobr et al. [26] & Healthy piglets & SB versus $6 \mathrm{ml} / \mathrm{kg}$ versus $10 \mathrm{ml} / \mathrm{kg}$ & VCAM-1, ICAM-1 \\
\hline Murphy et al. [208] & LPS aspiration in rabbits & $12 \mathrm{ml} / \mathrm{kg}$ versus $5 \mathrm{ml} / \mathrm{kg}$, PEEP 10 to 12 & TNF-a \\
\hline Oliveira-Junior et al. [209] & Healthy rats & $42 \mathrm{ml} / \mathrm{kg}$ versus $7 \mathrm{ml} / \mathrm{kg}$ & TNF- $a, I L-1 \beta$ \\
\hline O'Mahony et al. [13] & LPS i.p. in mice & SB versus $10 \mathrm{ml} / \mathrm{kg}$ & IL-6, KC, MIP-2, TNF-a \\
\hline Schortgen et al. [210] & P. aeruginosa aspiration in rats & $\begin{array}{l}27 \mathrm{ml} / \mathrm{kg} \text { versus } 6 \mathrm{ml} / \mathrm{kg} \text { versus } 6 \mathrm{ml} / \mathrm{kg} \text {, PEEP } 8 \\
\text { versus PLV versus SB }\end{array}$ & TNF-a \\
\hline Vaschetto et al. [14] & LPS aspiration in rats & $15 \mathrm{ml} / \mathrm{kg}$, PEEP 0 versus $6 \mathrm{ml} / \mathrm{kg}$, PEEP 5 & IL-6, TNF-a \\
\hline Vreugdenhil et al. [211] & Healthy rats & $\begin{array}{l}32 \mathrm{cmH}_{2} \mathrm{O} \text { versus } 32 \mathrm{cmH}_{2} \mathrm{O}, \text { PEEP } 6 \text { versus } \\
14 \mathrm{cmH}_{2} \mathrm{O}, \mathrm{PEEP} 6\end{array}$ & MIP-2 \\
\hline Wolthuis et al. [212] & Healthy mice & $15 \mathrm{ml} / \mathrm{kg}$ versus $8 \mathrm{ml} / \mathrm{kg}$ & IL-6, KC \\
\hline
\end{tabular}

AIP, above inflection point; aPC, activated protein C; ARDS, acute respiratory distress syndrome; GRO, growth-regulated oncogene; ICAM, intercellular adhesion molecule; IL-1RA, interleukin-1 receptor antagonist; i.p., intraperitoneal; KC, keratinocyte-derived chemokine; LPS, lipopolysaccharide; MCP, monocyte chemoattractant protein; MIP, macrophage inflammatory protein; PAI, plasminogen activator inhibitor; PEEP, positive end-expiratory pressure (in $\mathrm{cmH}_{2} \mathrm{O}$ ); $\mathrm{PLV}$, partial liquid ventilation; SB, spontaneous breathing; SFasL, soluble Fas ligand; sICAM, soluble intercellular adhesion molecule; SP-D, surfactant protein D; STNFR, soluble TNF-a receptor; TATc, thrombin-antithrombin complex; tPA, tissue-type plasminogen activator; VCAM, vascular cell adhesion molecule; VEGF, vascular endothelial growth factor.

TNF- $\alpha$ stimulates mesangial cells to produce a variety of vasoactive mediators in vitro (Table 3) [60-69]. Piepot and colleagues [70] showed impaired endotheliumdependent arterial relaxation after TNF- $\alpha$ exposure. By disturbing the balance between vasoconstriction and vasodilatation, TNF- $\alpha$ is thus potentially capable of reducing glomerular blood flow and glomerular filtration rate [71]. Additionally, TNF- $\alpha$ induced downregulation of angiotensin (Ang)-II type-1 receptor expression in vivo, which may explain the frequently observed vasodilation during sepsis [72].

Tubular epithelial cell shedding and tubular obstruction play a role in renal dysfunction. Glynne and colleagues [73] incubated proximal tubular epithelial cells with 
Table 3. Potential effects on the kidney of mediators released during mechanical ventilation

\begin{tabular}{|c|c|c|}
\hline Mediator & Effects on kidney & References \\
\hline \multicolumn{3}{|l|}{ Pro-inflammatory } \\
\hline \multirow[t]{8}{*}{ TNF-a } & $\begin{array}{l}\text { Stimulated expression of TGF- } \beta \text {, RANTES, MIP-2, MCP-2, IL-1 } \beta \text {, TNF- } a \text {, T-cell activation 3, IL-6, phospholipase-A2, } \\
\text { LIF. MHC-I upregulation }\end{array}$ & {$[37-40,43]$} \\
\hline & $\begin{array}{l}\text { Leukocyte infiltration through MCSF, MCP-1, GRO- } a, \beta, y, \text { ENA-78, GCP-2, IL-8, MIP-1 } \beta \text { and } 3 a \text {, RANTES, ICAM-1, } \\
\text { VCAM-1, L-selectin }\end{array}$ & [44-49] \\
\hline & $\begin{array}{l}\text { Death receptor- and mitochondrial-mediated apoptosis and ceramide signaling. Necrosis through ROS. } \\
\text { Downregulation of anti-apoptotic proteins. }\end{array}$ & {$[50-54,56-59]$} \\
\hline & Production of vasoactive mediators: PAF, ET-1, PGs, adenosine, NO. Downregulation Ang-II-R & {$[60-69,72]$} \\
\hline & NO tubular epithelial cell shedding. Decreased proliferation of tubular and mesangial cells & {$[73,74]$} \\
\hline & Increased PAl-1 gene expression, increased TF production with fibrin deposition & {$[75,76]$} \\
\hline & Decreased gene expression for urea, glucose, sodium and chloride transporters/channels & [77-80] \\
\hline & Decreased gene expression of nuclear hormone receptor $L X R$, its target genes and coactivators & [81] \\
\hline \multirow{7}{*}{$\| L-1 \beta$} & Stimulated expression of IL-6, IL-8, LIF, ceramide. MHC-I upregulation & {$[40,43,87-89]$} \\
\hline & Increased expression of MCP-1, GMCSF, MSF, ENA-78, RANTES, MIP-1ß, ICAM-1 & [90-93] \\
\hline & Downregulation of Ang-II-R. Expression of NO, PGE2 & {$[39,72,94,95]$} \\
\hline & Stimulated growth of glomerular epithelial cells & {$[96]$} \\
\hline & Increased TF expression and activity, upregulation of tPA and PAI-1 & {$[97,98]$} \\
\hline & Decreased gene expression for urea, glucose, sodium and chloride transporters/channels & [77-80] \\
\hline & Decreased gene expression of nuclear hormone receptor LXR, its target genes and coactivators & {$[81]$} \\
\hline \multirow[t]{7}{*}{ IL-6 } & TNF-a, IL-1 $\beta$ stimulation. Increased ICAM-1, P-selectin expression with neutrophil infiltration & [105-107] \\
\hline & Increased survival, upregulation of pro- and anti-apoptotic genes & [108] \\
\hline & Decreased expression of Ang-II-R & [72] \\
\hline & Increased oxidative stress, but increased expression of HO-1, Ref-1 & {$[105,106]$} \\
\hline & Proliferation of rat mesangial and tubular cells, increased HGF and met-c receptor. Conflicting reports & [109-111] \\
\hline & Decreased gene expression for urea, glucose and chloride transporters & [77-79] \\
\hline & Abrogation of protective effect of hyperlipidemia & [115] \\
\hline \multicolumn{3}{|c|}{ Anti-inflammatory } \\
\hline \multirow[t]{5}{*}{ IL-10 } & Decreased synthesis of TNF- $a$ and IL-1 $\beta$ & {$[118,119]$} \\
\hline & Contradictory effects on ICAM-1 expression and leukocyte infiltration & {$[118,120]$} \\
\hline & Prevention of apoptosis and necrosis. Decreased cell cycle activity & [118] \\
\hline & Reduction of VEGF, iNOS and nitrite formation & {$[118,121]$} \\
\hline & Proliferation of mesangial cells & {$[122-124]$} \\
\hline \multirow[t]{2}{*}{ STNFR } & Decreased expression of TNF-a, MCP-1 & [71] \\
\hline & Inhibition of apoptosis, decreased cell proliferation and fibrosis & [128-130] \\
\hline \multirow[t]{2}{*}{ IL-1RA } & Decreased gelatinase B, stromelysin, MCP-1 and IL-8 & {$[132,133]$} \\
\hline & Decreased ICAM-1 expression and leukocyte infiltration & [134-138] \\
\hline \multicolumn{3}{|l|}{ Chemotactic } \\
\hline \multirow[t]{2}{*}{ IL-8 } & Increased COX1 and PGE2 expression & [145] \\
\hline & Alterations in glomerular basement membrane sulfate metabolism & [146] \\
\hline \multirow[t]{3}{*}{ MIP-2 } & Increased MCP-1, RANTES, MIP-2 & [151] \\
\hline & Decreased neutrophil influx & {$[152,153]$} \\
\hline & Decreased fibrin deposition & [152] \\
\hline \multirow[t]{4}{*}{$K C=G R O-a$} & Increased MCP-1, RANTES, MIP-2, KC & [151] \\
\hline & Neutrophil infiltration & [153] \\
\hline & Stimulated proliferation of medullary collecting duct cells & [154] \\
\hline & Increased COX1 and PGE2 synthesis & [145] \\
\hline \multirow[t]{5}{*}{ MCP-1 } & Increased IL-6 & [155] \\
\hline & Increased ICAM-1 expression, chemotaxis and haptotaxis, monocyte/macrophage infiltration & [155-165] \\
\hline & Increased apoptosis & [164] \\
\hline & Increased fibrosis, TGF- $\beta$, collagen deposits & [165-167] \\
\hline & Decreased nephrin & [168] \\
\hline
\end{tabular}


Table 3. Continued

\begin{tabular}{|c|c|c|}
\hline Mediator & Effects on kidney & References \\
\hline \multicolumn{3}{|c|}{ Coagulation/fibrinolysis } \\
\hline \multirow[t]{2}{*}{ Active PAl-1 } & Increased leukocyte infiltration & [169] \\
\hline & Fibrin, collagen deposits, increased fibronectin, TGF- $\beta$, decreased urokinase and fibrosis & {$[169-172]$} \\
\hline \multirow[t]{2}{*}{ tPA } & Conflicting reports on leukocyte infiltration & {$[175,178]$} \\
\hline & Conflicting reports on fibrosis & {$[175-178]$} \\
\hline \multirow[t]{6}{*}{$\mathrm{aPC}$} & Decreased TNF-a, IL-6, IL-8, IL-18 & [180-182] \\
\hline & Decreased KC, MIP-2, MCP-1, suppression of leukocyte rolling, adhesion and infiltration & [180-184] \\
\hline & Decreased apoptosis, necrosis & [180-185] \\
\hline & Decreased nitrosative stress & {$[185]$} \\
\hline & $\begin{array}{l}\text { Decreased adrenomedullin, iNOS, angiotensin (II), ACE. Increased renal and peritubular blood flow, } \\
\text { decreased permeability }\end{array}$ & {$[180,181,184]$} \\
\hline & Decreased extracellular matrix depositions & {$[180,185]$} \\
\hline \multicolumn{3}{|l|}{ Miscellaneous } \\
\hline \multirow[t]{7}{*}{ VEGF } & Decreased MCP-1, ICAM-1, leukocyte infiltration & [188] \\
\hline & Decreased apoptosis and necrosis & [189-192] \\
\hline & Stimulated eNOS and NO expression & {$[193,194]$} \\
\hline & Increased permeability & {$[195,196]$} \\
\hline & Increased proliferation of glomerular cells, podocytes, mesangial cells, fibroblasts and capillaries & {$[192,194,213-220]$} \\
\hline & Conflicting reports of fibrosis and sclerosis & {$[194,217,219-221]$} \\
\hline & Sustained nephrin expression & [221] \\
\hline sFasL & Increased apoptosis & [10] \\
\hline
\end{tabular}

ACE, angiotensin converting enzyme; Ang-II-R, angiotensin-II receptor; aPC, activated protein C; COX, cyclooxygenase; ENA, epithelial neutrophil activating protein; eNOS, endothelial nitric oxide synthase; ET, endothelin; GCP, granulocyte chemotactic peptide; GMCSF, granulocyte macrophage colony-stimulating factor; GRO, growth related oncogene; HGF, hepatocyte growth factor; HO, heme-oxygenase; ICAM, intercellular adhesion molecule; IL-1RA, interleukin-1 receptor antagonist; iNOS, inducible nitric oxide; $K C$, keratinocyte-derived chemokine; LIF, leukemia inhibitory factor; $L X R$, liver $X$ receptor/retinoid $X$ receptor; $M C P$, monocyte chemoattractant protein; MCSF, macrophage colony stimulating factor; MHC, major histocompatibility complex; MIP, macrophage inflammatory protein; MSF, migration stimulating factor; NO, nitric oxide; PAF, platelet activating factor; PAI, plasminogen activator inhibitor; PG, prostaglandin; RANTES, regulated upon activation, normal T-cell expressed, and secreted; Ref, restriction factor; ROS, reactive oxygen species; sFasL, soluble Fas ligand; sTNFR, soluble TNF-a receptor; TF, tissue factor; TGF, transforming growth factor; TPA, tissue type plasminogen activator; VCAM, vascular cell adhesion molecule; VEGF, vascular endothelial growth factor.

TNF- $\alpha$ and observed disruption of the actin cytoskeleton and elongation of cells and shedding of viable, apoptotic and necrotic cells dependent on nitric oxide (NO). Cell shedding was accompanied by dispersal of $\beta 1$-integrins and E-cadherin. The same authors also found decreased proximal tubule epithelial cell proliferation, an effect that was also observed in mesangial cells $[73,74]$.

TNF- $\alpha$-induced histologic kidney damage is frequently characterized by glomerular fibrin deposition. By stimulating renal plasminogen activator inhibitor (PAI)-1 gene expression and increasing the production of tissue factor by mesangial and endothelial cells, TNF- $\alpha$ can contribute to fibrin deposition $[75,76]$.

In a series of animal experiments, Schmidt and colleagues [77-80] hypothesized a role for urea, glucose, sodium and chloride transporters in sepsis-associated tubular dysfunction. Within hours after lipopolysaccharide injection in mice they showed decreased renal blood flow and glomerular filtration and impaired tubular sodium handling associated with decreased levels of the aforementioned transporters. In TNF- $\alpha$-challenged mice they found significant downregulation of genes coding for urea, glucose, sodium and chloride transporters as well as for chloride channels and $\mathrm{Na}^{+} / \mathrm{K}^{+}$-ATPase- $\alpha_{1}$ compared to wild-type mice.

In proximal tubule cells in vitro, TNF- $\alpha$ caused a downregulation of gene expression of the nuclear hormone receptor liver $\mathrm{X}$ receptor/retinoid $\mathrm{X}$ receptor (LXR) and several of its target genes and coactivators [81]. During the acute phase TNF- $\alpha$ interferes with lipid metabolism in the kidney, with potential subsequent effects on the anti-infective and anti-inflammatory properties of lipids [82].

\section{Interleukin-1 $\beta$}

Cells of the innate immune system recognize microbial products and products released from dying and damaged cells, leading to the formation of complex proteins, termed inflammasomes $[83,84]$. Activation of caspase 1 by the inflammasome leads to cleavage and subsequent activation of IL-1 $\beta$ [85]. Glomerular endothelial cells, cortical tubular epithelial cells, podocytes and mesangial cells are capable of IL-1 $\beta$ production [86]. Despite its central role in the response to cell damage and microbes, surprisingly little in vivo research has focused on the role of IL-1 $\beta$ in acute kidney disease. IL-1 $\beta$ has been 
implicated in inflammation and cell recruitment, vasoactivity, coagulation and fibrinolysis, and regulation of chloride, urea, sodium and glucose transporters (Table 3).

Through NF- $\mathrm{B}$ signaling IL- $1 \beta$ stimulates human renal proximal tubular epithelial cells to produce IL-6 [87]. In mesangial cells, others showed IL-1 $\beta$-driven expression of ceramide, IL-6, IL- 8 and leukemia inhibitory factor $[40,55,88,89]$. Like TNF- $\alpha$, IL- $1 \beta$ is also capable of upregulating MHC class I expression in mesangial cells [43].

In mesangial and epithelial cell cultures, IL-1 $\beta$ induced upregulation of a multitude of chemoattractants, including $\mathrm{CC}$ and $\mathrm{CXC}$ chemokines [45,90-92]. Following chemoattraction, IL-1 $\beta$ also stimulates expression of ICAM-1 on mesangial cells, thereby facilitating leukocyte adhesion [93].

IL-1 $\beta$ is also involved in hemodynamic instability during septic shock. By downregulating Ang-II type-I receptors, IL-1 $\beta$ may be partially responsible for the decreased reactivity to vasoconstrictors [72]. Additionally, in mesangial cells, IL-1 $\beta$, through inducible nitric oxide synthase (iNOS), caused increased production of $\mathrm{NO}$, known for its vasodilatatory effects, and prostaglandin $(\mathrm{PG}) \mathrm{E}_{2}$, which has potential vasodilatory properties $[39,94,95]$.

Data on the effects of IL-1 $\beta$ cell proliferation are limited. Tateyama and colleagues [96] showed that IL-1 $\beta$ could function as an autocrine growth factor for rat glomerular epithelial cells in vitro.

IL-1 $\beta$ can affect both coagulation and fibrinolysis in vitro. In mesangial cells, IL-1 $\beta$ upregulated tissue factor expression by a protein kinase $\mathrm{C}$-dependent pathway, with an effect on tissue factor activity only when cells were rendered apoptotic [97]. Also in these cells, IL-1 $\beta$ was capable of inducing the fibrinolytic enzyme tissue type plasminogen activator (tPA), but also its inhibitor PAI-1 [98]. The effects of IL-1 $\beta$ on coagulation and fibrinolysis in the kidney in vivo remain unknown.

In the aforementioned series of animal experiments, Schmidt and colleagues [77-80] also found that IL-1 $\beta$ challenged mice significantly downregulated genes coding for urea, glucose, sodium and chloride transporters as well as for chloride channels and $\mathrm{Na}^{+} / \mathrm{K}^{+}$-ATPase- $\alpha_{1}$ compared to wild-type mice. This implicates IL-1 $\beta$ in sepsis-associated tubular dysfunction with decreased glomerular filtration rate, failure of urine concentration, decreased urine osmolality, increased fractional sodium excretion and glucosuria.

In human proximal tubule cells in vitro, IL-1 $\beta$, like TNF- $\alpha$, caused downregulation of gene expression of the nuclear hormone receptor LXR and several of its target genes and also of its coactivators [81]. The authors suggest a role for IL-1 $\beta$ in lipid metabolism in the kidney during the acute phase.

\section{Interleukin-6}

The exact nature of IL- 6 remains the subject of debate - it has been extensively described as both pro- and antiinflammatory [99,100]. IL-6 levels increase during hypoxia, tissue damage and organ failure [101-103] and predict mortality in patients with acute renal failure [104]. In the kidney, IL-6 is involved in inflammation, leukocyte adhesion and infiltration, apoptosis and survival, vasoactivity, prevention of oxidative stress, cell proliferation and lipid homeostasis during the acute phase (Table 3).

Ischemia/reperfusion (I/R) studies with IL-6 knock-out mice showed decreased levels of renal TNF- $\alpha$ and IL- $1 \beta$ compared to wild type [105]; this was accompanied by downregulated expression of ICAM-1 and P-selectin and decreased neutrophil infiltration [105-107].

The role of IL- 6 in apoptosis and survival is complex. In cisplatin-induced renal failure, mice lacking IL-6 had better survival rates despite decreased renal function. This was associated with upregulation of both pro- and anti-apoptotic genes [108]. The authors explain these phenomena by the fact that the upregulation of proapoptotic genes disappears after 24 hours, while antiapoptotic genes remain upregulated for 72 hours [108]. Others also found a positive effect on survival in IL-6 knock-out mice with improved renal function $[105,106]$.

In mice exposed to intravenous IL-6, Schmidt and colleagues [72] found decreased expression of Ang-II type-I receptors, which are involved in vasoconstriction, potentially explaining vasodilatation during shock. In an $\mathrm{I} / \mathrm{R}$ model and a mercury chloride-induced model of acute renal failure, IL- 6 knock-out mice and mice treated with anti-IL-6 antibodies had lower levels of oxidative stress and NO-dependent oxidative stress. In addition, IL- 6 bound to soluble IL- 6 receptor, likely shedded from neutrophils during AKI, increased gene expression of heme oxygenase- 1 and restriction factor-1, both known to protect against oxidative stress $[105,106]$.

Conflicting reports delineate a role for IL-6 in proliferation of various kidney cells, associated with tissue repair and regeneration (Table 3) [109-114].

Similar to TNF- $\alpha$ and IL-1 $\beta$, Schmidt and colleagues [77-79] hypothesized a role for urea, glucose and chloride transporters in sepsis-associated tubular dysfunction with failure of urine concentration, decreased urine osmolality and glucosuria. In IL-6-challenged mice they found significant downregulation of genes coding for urea, glucose and chloride transporters as well as for chloride channels and $\mathrm{Na}^{+} / \mathrm{K}^{+}-\mathrm{ATPase}-\alpha_{1}$ expression compared to wild-type mice, though to a lesser extent than TNF- $\alpha$ and IL- $1 \beta$.

Poloxamer 407 induces hyperlipidemia that protects against renal $\mathrm{I} / \mathrm{R}$ dysfunction. This was associated with decreased plasma levels of IL-6, but recombinant IL-6 
infusion abrogated these effects. These results were confirmed in apolipoprotein-E- and angiopoietin-like 3-deficient mice, which suffer from hypercholesterolemia and hypolipidemia, respectively [115].

\section{Anti-inflammatory \\ Interleukin-10}

IL-10 exerts its anti-inflammatory effect through inhibition of MHC class II-associated antigen presentation and by decreasing circulating levels of CC and CXC chemokines [116]. However, in a dose-dependent manner, IL-10 can also promote inflammation through effects on $B$ cells and natural killer cells and by stimulating cytokine production [116]. Increased levels of IL-10 predicted mortality in patients with acute renal failure and, interestingly, patients with specific IL-10 gene polymorphisms required less renal support during sepsis from pneumonia [104,117]. The effects of IL-10 on the kidney involve effects on inflammation, inflammatory cell recruitment and infiltration, apoptosis, necrosis and cell cycle activity, vasoactivity and cell proliferation (Table 3).

In vivo studies in different models of AKI, intravenous IL-10 administration decreased TNF- $\alpha$ production and prevented creatinine increase in mice [118]. Mesangial cells in vitro showed less production of TNF- $\alpha$ and IL-1 $\beta$ after stimulation with lipopolysaccharide in the presence of IL-10 [119]. Deng and colleagues [118] reported decreased ICAM-1 expression in mice during kidney injury and IL-10 injection; histological analysis also revealed decreased cast formation and leukocyte infiltration. Contradictory to these findings was an observation made by Chadban and colleagues [120] showing increased ICAM-1 expression on rat mesangial cells after stimulation with IL-10. In mice, administration of IL-10 prevented both apoptosis and necrosis, mainly in the outer stripe of the kidney, after cisplatin and I/R-induced kidney injury. IL-10 also decreased cell cycle activity [118].

IL-10 addition to glomerular epithelial cells in vitro reduced VEGF, a potent modulator of capillary permeability [121]. In vivo, IL-10 decreased iNOS, and in in vitro culture of cortical tubule cells, IL-10 exposure decreased nitrite formation [118].

In vitro experiments showed proliferation-stimulating effects of IL-10 on mesangial cells through platelet derived growth factor receptor $\alpha$ and $\beta$, but also upregulation of IL-10 mRNA, suggesting a possible autocrine mechanism [122-124]. These in vitro results were confirmed in vivo [124].

\section{Soluble tumor necrosis factor-a receptor}

Cleavage of the extracellular domain of the TNF- $\alpha$ receptor (TNF- $\alpha \mathrm{R})$ leads to soluble TNF- $\alpha \mathrm{R}$ (sTNF- $\alpha \mathrm{R})$ capable of binding and thereby inactivating TNF- $\alpha$. Blood sTNF- $\alpha$ R levels predicted acute renal failure in patients with septic shock and acute lung injury $[125,126]$. In rats subjected to ischemia reperfusion injury, sTNF- $\alpha \mathrm{R}$ prevented loss of renal function, and prevented expression of TNF- $\alpha$ and monocyte chemotactic protein (MCP)-1 [127]. Without changes in hypotension, apoptosis, leukocyte infiltration or morphology, sTNF- $\alpha$ R preserved glomerular filtration rate, suggesting a role for vasoactive mediators [71]. Apoptosis of mesangial cells co-cultured with interferon$\gamma$-stimulated macrophages was inhibited by sTNF- $\alpha \mathrm{R}$ in vitro [128]. In in vivo studies in rats with unilateral ureteral obstruction, administration of sTNF- $\alpha$ R decreased tubular and interstitial cell proliferation and apoptosis and prevented renal fibrosis (Table 3) [129,130].

\section{Interleukin-1 receptor antagonist}

IL-1 receptor antagonist (IL-1RA) is a physiological inhibitor of IL- $1 \beta$ activity through competitive binding to the IL-1 $\beta$ receptor. Recombinant IL-1RA administration during sepsis showed a mortality benefit of almost 5\% [131]. In mesangial cells addition of IL-1RA decreased gelatinase $\mathrm{B}$, stromelysin, MCP-1 and IL- 8 RNA and protein levels after stimulation with IL- $1 \alpha$ and IL-1 $\beta$ $[132,133]$. In in vivo models of anti-glomerular basement membrane antibody glomerulonephritis and renal I/R treatment with IL-1RA resulted in improved kidney function, decreased expression of ICAM-1 and reduced renal histological damage, including decreased infiltration of lymphocytes, neutrophils and macrophages and less apoptosis (Table 3) [134-138].

\section{Chemotactic}

\section{Interleukin-8}

The chemokine IL- 8 is produced mainly by macrophages, but also by renal tubular epithelial cells, mesangial cells and podocytes [139-142]. IL-8 levels predict the development of AKI, duration of MV and mortality in patients with AKI $[104,143,144]$. Exposure of mesangial cells to IL-8 in vitro leads to selective expression of cyclooxygenase (COX)1, but not COX2, and subsequent synthesis of $\mathrm{PGE}_{2}$ [145]. In vivo infusion of IL-8 in rats causes increased albuminuria, mediated through alterations of sulfate metabolism by the glomerular basement membrane (Table 3) [146].

\section{Macrophage inflammatory protein-2}

Macrophage inflammatory protein (MIP)-2, a member of the superfamily of chemokines, is a potent chemotactic factor for neutrophils and stimulates the production of other inflammatory mediators such as IL- $1 \beta$ and TNF- $\alpha$ [147]. In kidneys, mesangial cells and glomerular epithelial cells stimulated by NO or IL-1 $\beta$ are capable of 
synthesizing MIP-2 [148-150]. Exposure of mesangial cells to MIP-2 in vitro stimulates the release of MCP-1, RANTES and also MIP-2 [151]. Specific blocking of MIP-2 in in vivo models of shiga toxin-induced renal inflammation and anti-glomerular basement membrane antibody glomerulonephritis prevented renal neutrophil influx and fibrin deposition and decreased proteinuria (Table 3) [152,153].

\section{Keratinocyte chemoattractant}

Keratinocyte chemoattractant (KC), also known as growth related oncogene or CXCL1, in mesangial cells increased production of pro-inflammatory mediators such as MCP-1, RANTES, MIP-2 and KC [151]. KC exhibited neutrophil-attracting properties as shown in a mouse model of shiga toxin-induced renal injury [153]. In vitro $\mathrm{KC}$ stimulated proliferation of inner medullary collecting duct cells [154]. KC also stimulates mesangial cells to produce COX1 and enhances $\mathrm{PGE}_{2}$ synthesis (Table 3) [145].

\section{Monocyte chemotactic protein-1}

MCP-1, or chemokine ligand 2, stimulates IL-6 synthesis in vitro through NF- $\mathrm{kB}$ and activator protein-1 activation [155]. In vitro and in several animal models of chronic kidney injury, MCP-1 has been shown to increase ICAM-1 expression leading to increased chemotaxis, haptotaxis, directional cell motility up a gradient of cellular adhesion sites, and leukocyte infiltration; macrophages and monocytes were mainly involved [155-165]. In rats transfected with a MCP-1 antagonist and protein overload proteinuria, decreased numbers of apoptotic cells were observed compared to wild type [164]. In models of crescentic nephritis and glomerulonephritis, blocking MCP-1 was shown to decrease collagen type I and IV deposition and decrease transforming growth factor- $\beta$ levels $[165,166]$. Additionally, MCP-1 increased fibronectin production in mesangial cells, whereas finbronectin levels decreased in diabetic MCP-1 knockout mice [167]. In vitro studies of podocytes showed decreased levels of nephrin, which is necessary for the proper functioning of the renal filtration barrier, after exposure to MCP-1 (Table 3) [168].

\section{Coagulation and fibrinolysis Plasminogen activator inhibitor-1}

In patients with acute lung injury, PAI-1 is a prognostic factor for the development of acute renal failure [126]. In PAI-1 knock-out models or models overexpressing PAI-1 with anti-glomerular basement membrane glomerulonephritis, PAI-1 increases leukocyte infiltration, crescent formation, fibrin deposits, fibronectin synthesis and collagen accumulation [169-171]. Similar results were found in rodents with unilateral ureteral obstruction with increased transforming growth factor- $\beta 1$ levels and decreased levels of urokinase [172]. Functionally, PAI-1 knock-out mice showed decreased albuminuria in a diabetes model (Table 3) [173].

\section{Tissue type plasminogen activator}

Similar to PAI-1, tPA is mainly involved in fibrosis through matrix metalloproteinase (MMP)-9 stimulation, myofibroblast activation and prevention of apoptosis of myofibroblasts and fibroblasts [174]. In tPA knock-out studies in I/R or unilateral ureteral obstruction models, tPA was shown to increase neutrophil influx, but other effects mainly concerned tissue remodeling, although conflicting reports exist [175-178] (Table 3).

\section{Activated protein C}

In patients with severe sepsis, baseline activated protein $\mathrm{C}$ (aPC) levels were inversely associated with worsening renal function and/or subsequent dialysis and treatment, whereas treatment with aPC was associated with improved renal function [179]. The anti-inflammatory effects of aPC are shown in the downregulation of the expression of TNF- $\alpha$, IL-6, IL-8 and IL-18 [180-182]. By decreasing $\mathrm{KC}$ and MIP-2 protein and MCP-1 mRNA, aPC potentially prevents inflammatory cell recruitment [181-183]. Additionally, aPC suppresses leukocyte rolling and adhesion [184]. Histologically this leads to decreased leukocyte influx and also decreased renal myeloperoxidase levels [180,181]. In the same histological specimens, aPC prevented renal necrosis and apoptosis of glomerular and endothelial cells and podocytes [180185]. In a model of diabetes, Isermann and colleagues [185] found aPC to have an antioxidant effect, decreasing nitrosative stress by decreasing kidney nitrotyrosine levels. Positive hemodynamic effects have been observed in various models, whereby aPC increased renal blood flow and peritubular flow, potentially by the observed decrease in adrenomedullin, iNOS, angiotensinogen mRNA, Ang converting enzyme and Ang-II [184]. Vascular permeability is also decreased by aPC $[180,181]$. The anticoagulant properties of aPC are highlighted by a decrease in circulating fibrin degradation products and decreased extracellular matrix depositions [180,185]. Combined, these effects of aPC preserve renal function as measured by creatinine, blood urea nitrogen levels and proteinuria (Table 3) [181-184].

\section{Miscellaneous}

\section{Vascular endothelial growth factor}

In a rodent model of ventilator-induced lung injury, Choi and colleagues [18] indicated a role for VEGF in endothelial NOS-mediated vasopermeability in lungs and kidneys. VEGF is a potent endothelial cell mitogen, promotes endothelial cell differentiation and survival, 
stimulates angiogenesis and enhances vascular permeability. While deleterious in some forms of renal disease, VEGF may contribute to recovery in others [186,187].

In rodent models of glomeruolonephritis, intravenous VEGF decreased MCP-1 and ICAM-1 levels with a subsequent decrease in infiltrating leukocytes [188]. VEGF prevented glomerular and tubulointerstitial cell apoptosis and necrosis in models of hemolytic uremic syndrome and mesangio-proliferative nephritis, which was confirmed in vitro [189-192]. In vivo VEGF stimulated endothelial nitric oxide synthase expression in rats in a remnant kidney model, and in glomerular endothelial cells this increased NO expression [193,194]. One of the characteristics of VEGF is enhancement of vascular permeability; this was confirmed in vitro $[195,196]$. The proliferative effects of VEGF have been well described, both in vivo and in vitro, but these properties are likely of limited interest for the development of AKI (Table 3).

\section{Soluble Fas ligand}

sFasL is up to 1,000-fold less active than membranebound FasL in inducing apoptosis and has even been suggested to have antagonistic properties [197,198]. However, Imai and colleagues [10] showed apoptotic activity of serum of mechanically ventilated rabbits on renal tubular cells in vitro, which could be blocked by an anti-sFasL Fas:Ig fusion protein (Table 3).

\section{Mediators - theory or causal relationship?}

Central in the biotrauma hypothesis is the increase in intra-pulmonary mediator levels and the spill-over of these mediators from the lung into the systemic circulation. Several mediators are systemically increased during MV (Tables 1 and 2), although the exact cellular origins of the systemically measured mediators remains unknown [7]. Most of the mediators increased during MV have potential and well described effects on the kidney.

Most studies have focused on pro-inflammatory and chemotactic mediators, especially TNF- $\alpha$, IL- 6 and MIP-2. The effects of these pro-inflammatory mediators on the kidney have been studied to varying degrees. In vivo evidence indicates that TNF- $\alpha$ can cause and contributes to AKI, in contrast to IL-1 $\beta$ and MIP-2, for which sufficient in vivo data are lacking. IL-6 has been shown to be involved in AKI, but conflicting reports exist and no definite conclusion can be drawn. Much is known about the effects of anti-inflammatory and chemotactic mediators on the kidney. Strong evidence indicates a protective role for anti-inflammatory mediators, especially IL-10, in the development of AKI, but insufficient evidence exists to indicate a direct role in AKI for chemotactic mediators. Little is known about the potential effects on the kidney of some frequently studied mediators released during MV, such as soluble ICAM, soluble VCAM and sFasL. The potential of these mediators will remain unknown in the absence of studies on their possible effects on the kidney. Other mediators, for example, aPC and VEGF, have several well known effects on the kidney but have received little attention in studies on mediator release during MV. Studies of aPC and VEGF during MV have great potential to further delineate the effects of these mediators on the kidney.

IL-10, IL-8 and aPAI-1 all have predictive value for the development of AKI or AKI-associated mortality. Despite this, few studies have focused on the role of MV and, even though their increase may be an epiphenomenon, little is known about their potential role in the pathophysiology of AKI. Interestingly, we did not identify studies using specific blocking of mediators in vivo or specific knock-out models that could establish a causal relationship between $\mathrm{MV}$-induced mediator release and AKI. However, we describe a multitude of potential effects on the kidney of several mediators that can be blocked rather specifically now in both animal models and humans. For example, anakinra, a synthetic IL-1RA, and infliximab, a monoclonal antibody against TNF- $\alpha$, have found their way into clinical practice.

Before targeting mediators to prevent AKI in patients, care must be taken to learn from past experiences. Attempting to alter the course of sepsis, numerous studies have targeted a variety of mediators in critically ill patients, mainly suffering from sepsis. The rather disappointing results of these studies have led to insights into the possible mechanisms of failure in these studies. Several issues should be taken into account. The agent's biological activity, shown in vitro or in simple animal models, may not be replicable in humans. Dosage, timing and duration of the novel therapy are usually unknown. In most trials in critical care medicine the target population is heterogeneous, also including genetic polymorphisms. The complexity of mediator interdependency may also require the targeting of multiple mediators simultaneously or combined targeting of pro- and antiinflammatory mediators.

\section{Conclusion}

From a theoretical point of view, the systemic release of several mediators induced by MV may play an important role in the pathophysiology of AKI. However, evidence supporting this hypothesis or showing causal relationships is lacking for the studied mediators. Future studies should therefore not only focus on the release of mediators during MV and a possible relationship with AKI, but should also study in-depth the pathophysiology by which these mediators may contribute to AKI.

\section{Abbreviations}

$\mathrm{AKI}$, acute kidney injury; Ang, angiotensin; aPC, activated protein C; COX, cyclooxygenase; ICAM, intercellular adhesion molecule; IL, interleukin; IL-1RA, 
interleukin-1 receptor antagonist; iNOS, inducible nitric oxide synthase; I/R, ischemia/reperfusion; KC, keratinocyte chemoattractant; LXR, liver X-receptor/ retinoid X-receptor; $\mathrm{MCP}$, monocyte chemoattractant protein; $\mathrm{MHC}$, major histocompatibility complex; MIP, macrophage inflammatory protein; MV, mechanical ventilation; NF, nuclear factor; NO, nitric oxide; PAl, plasminogen activator inhibitor; PG, prostaglandin; sFasL, soluble Fas ligand; sTNF-aR, soluble TNF-a receptor; TNF, tumor necrosis factor; TNF-aR, TNF-a receptor; tPA, tissue type plasminogen activator; VCAM, vascular cellular adhesion molecule; VEGF, vascular endothelial growth factor.

\section{Competing interests}

The authors declare that they have no competing interests.

\section{Authors' contributions}

JWK performed the literature search and drafted the manuscript. RV performed the literature search and critically reviewed the manuscript. FDC critically reviewed the manuscript. FBP helped to draft the manuscript. ABJG conceived of the study and helped to draft the manuscript. All authors read and approved the final manuscript.

\section{Acknowledgements}

JWK was supported by a stipend from the Ter Meulen Fund, Royal Netherlands Academy of Arts and Sciences, The Netherlands.

\section{Author details}

'Department of Pediatric Intensive Care, VUmc Medical Center, 1007 MB Amsterdam, The Netherlands. ${ }^{2}$ Intensive Care, VUmc Medical Center, 1007 MB Amsterdam, The Netherlands. ${ }^{3}$ Departments of Anesthesiology and Critical Care Medicine, and Department of Clinical and Experimental Medicine, Università del Piemonte Orientale 'A Avogadro' Alessandria-Novara-Vercelli 13100, Italy. ${ }^{4}$ Department of Pediatric Intensive Care, ErasmusMC-Sophia Children's Hospital, 3000 CB Rotterdam, The Netherlands.

\section{Published: 16 August 2011}

\section{References}

1. Uchino S, Kellum JA, Bellomo R, Doig GS, Morimatsu H, Morgera S, Schetz M, Tan I, Bouman C, Macedo E, Gibney N, Tolwani A, Ronco C; Beginning and Ending Supportive Therapy for the Kidney (BEST Kidney) Investigators: Acute renal failure in critically ill patients: a multinational, multicenter study. JAMA 2005, 294:813-818.

2. Mehta RL, Pascual MT, Gruta CG, Zhuang S, Chertow GM: Refining predictive models in critically ill patients with acute renal failure. J Am Soc Nephrol 2002, 13:1350-1357.

3. Kuiper JW, Groeneveld AB, Slutsky AS, Plotz FB: Mechanical ventilation and acute renal failure. Crit Care Med 2005, 33:1408-1415.

4. Slutsky AS, Tremblay LN: Multiple system organ failure. Is mechanical ventilation a contributing factor? Am J Respir Crit Care Med 1998, 157:1721-1725

5. The Acute Respiratory Distress Syndrome Network: Ventilation with lower tidal volumes as compared with traditional tidal volumes for acute lung injury and the acute respiratory distress syndrome. The Acute Respiratory Distress Syndrome Network. N Engl J Med 2000, 342:1301-1308.

6. Tremblay LN, Slutsky AS: Ventilator-induced injury: from barotrauma to biotrauma. Proc Assoc Am Physicians 1998, 110:482-488.

7. Plotz FB, Slutsky AS, van Vught AJ, Heijnen CJ: Ventilator-induced lung injury and multiple system organ failure: a critical review of facts and hypotheses. Intensive Care Med 2004, 30:1865-1872.

8. Uhlig S: Ventilation-induced lung injury and mechanotransduction: stretching it too far? Am J Physiol Lung Cell Mol Physiol 2002, 282:L892-L896.

9. Ranieri M, Giunta F, Suter PM, Slutsky AS: Mechanical ventilation as a mediator of multisystem organ failure in acute respiratory distress syndrome. JAMA 2000, 284:43-44.

10. Imai Y, Parodo J, Kajikawa O, de Perrot M, Fischer S, Edwards V, Cutz E, Liu M, Keshavjee S, Martin TR, Marshall JC, Ranieri VM, Slutsky AS: Injurious mechanical ventilation and end-organ epithelial cell apoptosis and organ dysfunction in an experimental model of acute respiratory distress syndrome. JAMA 2003, 289:2104-2112.

11. Crimi E, Zhang H, Han RN, Del Sorbo L, Ranieri VM, Slutsky AS: Ischemia and reperfusion increases susceptibility to ventilator-induced lung injury in rats. Am J Respir Crit Care Med 2006, 174:178-186.
12. Dhanireddy S, Altemeier WA, Matute-Bello G, O'Mahony DS, Glenny RW, Martin TR, Liles WC: Mechanical ventilation induces inflammation, lung injury, and extra-pulmonary organ dysfunction in experimental pneumonia. Lab Invest 2006, 86:790-799.

13. O'Mahony DS, Liles WC, Altemeier WA, Dhanireddy S, Frevert CW, Liggitt D, Martin TR, Matute-Bello G: Mechanical ventilation interacts with endotoxemia to induce extrapulmonary organ dysfunction. Crit Care 2006, 10:R136-R144.

14. Vaschetto R, Kuiper JW, Chiang SR, Haitsma JJ, Juco JW, Uhlig S, Plotz FB, Corte FD, Zhang H, Slutsky AS: Inhibition of poly(adenosine diphosphateribose) polymerase attenuates ventilator-induced lung injury. Anesthesiology 2008, 108:261-268.

15. Kuiper JW, Versteilen AM, Niessen HW, Vaschetto RR, Sipkema P, Heijnen CJ, Groeneveld AB, Plotz FB: Production of endothelin-1 and reduced blood flow in the rat kidney during lung-injurious mechanical ventilation. Anesth Analg 2008, 107:1276-1283.

16. Haitsma JJ, Schultz MJ, Hofstra JJ, Kuiper JW, Juco J, Vaschetto R, Levi M, Zhang H, Slutsky AS: Ventilator-induced coagulopathy in experimental Streptococcus pneumoniae pneumonia. Eur Respir J 2008, 32:1599-1606.

17. Chen CM, Chou HC, Wang LF, Lang YD: Captopril decreases plasminogen activator inhibitor-1 in rats with ventilator-induced lung injury. Crit Care Med 2008, 36:1880-1885.

18. Choi WI, Quinn DA, Park KM, Moufarrej RK, Jafari B, Syrkina O, Bonventre JV, Hales CA: Systemic microvascular leak in an in vivo rat model of ventilatorinduced lung injury. Am J Respir Crit Care Med 2003, 167:1627-1632.

19. Calfee CS, Eisner MD, Parsons PE, Thompson BT, Conner ER Jr, Matthay MA, Ware LB: Soluble intercellular adhesion molecule- 1 and clinical outcomes in patients with acute lung injury. Intensive Care Med 2008, 35:248-257.

20. Eisner MD, Parsons P, Matthay MA, Ware L, Greene K: Plasma surfactant protein levels and clinical outcomes in patients with acute lung injury. Thorax 2003, 58:983-988.

21. Parsons PE, Eisner MD, Thompson BT, Matthay MA, Ancukiewicz M, Bernard $G R$, Wheeler AP: Lower tidal volume ventilation and plasma cytokine markers of inflammation in patients with acute lung injury. Crit Care Med 2005, 33:1-6.

22. Parsons $P E$, Matthay MA, Ware LB, Eisner MD: Elevated plasma levels of soluble TNF receptors are associated with morbidity and mortality in patients with acute lung injury. Am J Physiol Lung Cell Mol Physiol 2005, 288:L426-L431.

23. Ranieri VM, Suter PM, Tortorella C, De Tullio R, Dayer JM, Brienza A, Bruno F, Slutsky AS: Effect of mechanical ventilation on inflammatory mediators in patients with acute respiratory distress syndrome: a randomized controlled trial. JAMA 1999, 282:54-61.

24. Stuber F, Wrigge H, Schroeder S, Wetegrove S, Zinserling J, Hoeft A, Putensen $C$ : Kinetic and reversibility of mechanical ventilation-associated pulmonary and systemic inflammatory response in patients with acute lung injury. Intensive Care Med 2002, 28:834-841.

25. Ware LB, Matthay MA, Parsons PE, Thompson BT, Januzzi JL, Eisner MD: Pathogenetic and prognostic significance of altered coagulation and fibrinolysis in acute lung injury/acute respiratory distress syndrome. Crit Care Med 2007, 35:1821-1828.

26. Kobr J, Fremuth J, Pizingerova K, Fikrlova S, Jehlicka P, Honomichl P, Sasek L, Racek J, Topolcan O: Total body response to mechanical ventilation of healthy lungs: an experimental study in piglets. Physio/ Res 2010, 59:545-552.

27. Tracey KJ, Beutler B, Lowry SF, Merryweather J, Wolpe S, Milsark IW, Hariri RJ, Fahey TJ, III, Zentella A, Albert JD, et al:: Shock and tissue injury induced by recombinant human cachectin. Science 1986, 234:470-474.

28. Bertani T, Abbate M, Zoja C, Corna D, Perico N, Ghezzi P, Remuzzi G: Tumor necrosis factor induces glomerular damage in the rabbit. Am J Pathol 1989, 134:419-430.

29. Baud L, Oudinet JP, Bens M, Noe L, Peraldi MN, Rondeau E, Etienne J, Ardaillou R: Production of tumor necrosis factor by rat mesangial cells in response to bacterial lipopolysaccharide. Kidney Int 1989, 35:1111-1118.

30. Gomez-Guerrero C, Lopez-Armada MJ, Gonzalez E, Egido J: Soluble IgA and IgG aggregates are catabolized by cultured rat mesangial cells and induce production of TNF-alpha and IL-6, and proliferation. J Immunol 1994, 153:5247-5255.

31. Nakamura A, Johns EJ, Imaizumi A, Niimi R, Yanagawa Y, Kohsaka T: Role of angiotensin II-induced cAMP in mesangial TNF-alpha production. Cytokine 2002, 19:47-51. 
32. Noiri E, Kuwata S, Nosaka K, Tokunaga K, Juji T, Shibata Y, Kurokawa K: Tumor necrosis factor-alpha mRNA expression in lipopolysaccharide-stimulated rat kidney. Chronological analysis of localization. Am J Pathol 1994, 144:1159-1166.

33. Neale TJ, Ruger BM, Macaulay H, Dunbar PR, Hasan Q, Bourke A, MurrayMcIntosh RP, Kitching AR: Tumor necrosis factor-alpha is expressed by glomerular visceral epithelial cells in human membranous nephropathy. Am J Pathol 1995, 146:1444-1454.

34. Gomez-Chiarri M, Ortiz A, Lerma JL, Lopez-Armada MJ, Mampaso F, Gonzalez E, Egido J: Involvement of tumor necrosis factor and platelet-activating factor in the pathogenesis of experimental nephrosis in rats. Lab Invest 1994, 70:449-459.

35. Wuthrich RP, Glimcher LH, Yui MA, Jevnikar AM, Dumas SE, Kelley VE: MHC class II, antigen presentation and tumor necrosis factor in renal tubular epithelial cells. Kidney Int 1990, 37:783-792.

36. Jevnikar AM, Brennan DC, Singer GG, Heng JE, Maslinski W, Wuthrich RP, Glimcher LH, Kelley VE: Stimulated kidney tubular epithelial cells express membrane associated and secreted TNF alpha. Kidney Int 1991, 40:203-211.

37. Ramesh G, Reeves WB: TNF-alpha mediates chemokine and cytokine expression and renal injury in cisplatin nephrotoxicity. J Clin Invest 2002, 110:835-842.

38. Wu SH, Lu C, Dong L, Zhou GP, He ZG, Chen ZQ: Lipoxin A4 inhibits TNFalpha-induced production of interleukins and proliferation of rat mesangial cells. Kidney Int 2005, 68:35-46.

39. Pfeilschifter J, Pignat W, Leighton J, Marki F, Vosbeck K, Alkan S: Transforming growth factor beta 2 differentially modulates interleukin- 1 beta- and tumour-necrosis-factor-alpha-stimulated phospholipase A2 and prostaglandin E2 synthesis in rat renal mesangial cells. Biochem J 1990, 270:269-271.

40. Hartner A, Sterzel RB, Reindl N, Hocke GM, Fey GH, Goppelt-Struebe M: Cytokine-induced expression of leukemia inhibitory factor in renal mesangial cells. Kidney Int 1994, 45:1562-1571.

41. Bijuklic K, Sturn DH, Jennings P, Kountchev J, Pfaller W, Wiedermann CJ, Patsch JR, Joannidis M: Mechanisms of neutrophil transmigration across renal proximal tubular HK-2 cells. Cell Physiol Biochem 2006, 17:233-244.

42. Bijuklic K, Jennings P, Kountchev J, Hasslacher J, Aydin S, Sturn D, Pfaller W Patsch JR, Joannidis M: Migration of leukocytes across an endotheliumepithelium bilayer as a model of renal interstitial inflammation. Am J Physiol Cell Physiol 2007, 293:C486-C492.

43. Ikeda M, Minota S, Kano S: Regulation of MHC class I expression by inflammatory cytokines in rat mesangial cells. Nephron 1997, 76:90-95.

44. Pai R, Ha H, Kirschenbaum MA, Kamanna VS: Role of tumor necrosis factoralpha on mesangial cell MCP-1 expression and monocyte migration: mechanisms mediated by signal transduction. J Am Soc Nephrol 1996, 7:914-923.

45. Thorburn E, Kolesar L, Brabcova E, Petrickova K, Petricek M, Jaresova M, Slavcev A, Striz I: CXC and CC chemokines induced in human renal epithelial cells by inflammatory cytokines. APMIS 2009, 117:477-487.

46. Kamanna VS, Pai R, Bassa B, Kirschenbaum MA: Activation of mesangial cells with TNF-alpha stimulates M-CSF gene expression and monocyte proliferation: evidence for involvement of protein kinase $C$ and protein tyrosine kinase. Biochim Biophys Acta 1996, 1313:161-172.

47. Brennan DC, Jevnikar AM, Takei F, Reubin-Kelley VE: Mesangial cell accessory functions: mediation by intercellular adhesion molecule-1. Kidney Int 1990, 38:1039-1046.

48. Neumann B, Machleidt T, Lifka A, Pfeffer K, Vestweber D, Mak TW, Holzmann B, Kronke M: Crucial role of 55-kilodalton TNF receptor in TNF-induced adhesion molecule expression and leukocyte organ infiltration. J Immunol 1996, 156:1587-1593

49. Brady HR, Spertini $O$, Jimenez W, Brenner BM, Marsden PA, Tedder TF: Neutrophils, monocytes, and lymphocytes bind to cytokine-activated kidney glomerular endothelial cells through L-selectin (LAM-1) in vitro. J Immunol 1992, 149:2437-2444.

50. Wu X, Guo R, Chen P, Wang Q, Cunningham PN: TNF induces caspasedependent inflammation in renal endothelial cells through a Rho- and myosin light chain kinase-dependent mechanism. Am J Physiol Renal Physiol 2009, 297:F316-F326.

51. Misseri R, Meldrum DR, Dinarello CA, Dagher P, Hile KL, Rink RC, Meldrum KK: TNF-alpha mediates obstruction-induced renal tubular cell apoptosis and proapoptotic signaling. Am J Physiol Renal Physiol 2005, 288:F406-F411.

52. Cunningham PN, Dyanov HM, Park P, Wang J, Newell KA, Quigg RJ: Acute renal failure in endotoxemia is caused by TNF acting directly on TNF receptor-1 in kidney. J Immunol 2002, 168:5817-5823.

53. Wan B, Hao L, Qiu Y, Sun Z, Cao Q, Zhang Y, Zhu T, Wang H, Zhang Y: Blocking tumor necrosis factor-alpha inhibits folic acid-induced acute renal failure. Exp Mol Pathol 2006, 81:211-216.

54. Messmer UK, Briner VA, Pfeilschifter J: Tumor necrosis factor-alpha and lipopolysaccharide induce apoptotic cell death in bovine glomerular endothelial cells. Kidney Int 1999, 55:2322-2337.

55. Hannun YA: Functions of ceramide in coordinating cellular responses to stress. Science 1996, 274:1855-1859.

56. Huwiler A, Dorsch S, Briner VA, van den BH, Pfeilschifter J: Nitric oxide stimulates chronic ceramide formation in glomerular endothelial cells. Biochem Biophys Res Commun 1999, 258:60-65.

57. Huwiler A, Pfeilschifter J, van den BH: Nitric oxide donors induce stress signaling via ceramide formation in rat renal mesangial cells. J Bio/ Chem 1999, 274:7190-7195.

58. Hruby ZW, Cybulsky AV, Lowry RP: Effects of tumor necrosis factor on glomerular mesangial and epithelial cells in culture. Nephron 1990, 56:410-413.

59. Radeke HH, Meier B, Topley N, Floge J, Habermehl GG, Resch K: Interleukin 1-alpha and tumor necrosis factor-alpha induce oxygen radical production in mesangial cells. Kidney Int 1990, 37:767-775.

60. Baud L, Perez J, Friedlander G, Ardaillou R: Tumor necrosis factor stimulates prostaglandin production and cyclic AMP levels in rat cultured mesangial cells. FEBS Lett 1988, 239:50-54.

61. Topley N, Floege J, Wessel K, Hass R, Radeke HH, Kaever V, Resch K: Prostaglandin E2 production is synergistically increased in cultured human glomerular mesangial cells by combinations of IL-1 and tumor necrosis factor-alpha 1. J Immunol 1989, 143:1989-1995.

62. Kohan DE: Production of endothelin-1 by rat mesangial cells: regulation by tumor necrosis factor. J Lab Clin Med 1992, 119:477-484

63. Savic V, Stefanovic V, Ardaillou N, Ardaillou R: Induction of ecto-5'nucleotidase of rat cultured mesangial cells by interleukin- 1 beta and tumour necrosis factor-alpha. Immunology 1990, 70:321-326.

64. Marsden PA, Ballermann BJ: Tumor necrosis factor alpha activates soluble guanylate cyclase in bovine glomerular mesangial cells via an L-argininedependent mechanism. J Exp Med 1990, 172:1843-1852.

65. Marsden PA, Brenner BM: Transcriptional regulation of the endothelin-1 gene by TNF-alpha. Am J Physiol 1992, 262:C854-C861

66. Camussi G, Turello E, Tetta C, Bussolino F, Baglioni C: Tumor necrosis facto induces contraction of mesangial cells and alters their cytoskeletons. Kidney Int 1990, 38:795-802.

67. Floege J, Topley N, Wessel K, Kaever V, Radeke H, Hoppe J, Kishimoto T, Resch K: Monokines and platelet-derived growth factor modulate prostanoid production in growth arrested, human mesangial cells. Kidney Int 1990, 37:859-869.

68. Pfeilschifter J, Pignat W, Vosbeck K, Marki F: Interleukin 1 and tumor necrosis factor synergistically stimulate prostaglandin synthesis and phospholipase $\mathrm{A} 2$ release from rat renal mesangial cells. Biochem Biophys Res Commun 1989, 159:385-394.

69. Pfeilschifter $\mathrm{J}$ Muhl $\mathrm{H}$ : Interleukin 1 and tumor necrosis factor potentiate angiotensin II- and calcium ionophore-stimulated prostaglandin E2 synthesis in rat renal mesangial cells. Biochem Biophys Res Commun 1990, 169:585-595

70. Piepot HA, Groeneveld AB, van Lambalgen AA, Sipkema P: Tumor necrosis factor-alpha impairs endothelium-dependent relaxation of rat renal arteries, independent of tyrosine kinase. Shock 2002, 17:394-398.

71. Knotek M, Rogachev B, Wang W, Ecder T, Melnikov V, Gengaro PE, Esson M Edelstein CL, Dinarello CA, Schrier RW: Endotoxemic renal failure in mice: Role of tumor necrosis factor independent of inducible nitric oxide synthase. Kidney Int 2001, 59:2243-2249.

72 Schmidt C, Hocherl K, Kurt B, Moritz S, Kurtz A, Bucher M: Blockade of multiple but not single cytokines abrogates downregulation of angiotensin II type-I receptors and anticipates septic shock. Cytokine 2010, 49:30-38.

73. Glynne PA, Picot J, Evans TJ: Coexpressed nitric oxide synthase and apical beta(1) integrins influence tubule cell adhesion after cytokine-induced injury. J Am Soc Nephrol 2001, 12:2370-2383.

74. Martin M, Schwinzer R, Schellekens H, Resch K: Glomerular mesangial cells in local inflammation. Induction of the expression of MHC class II antigens by IFN-gamma. J Immunol 1989, 142:1887-1894. 
75. Sawdey MS, Loskutoff DJ: Regulation of murine type 1 plasminogen activator inhibitor gene expression in vivo. Tissue specificity and induction by lipopolysaccharide, tumor necrosis factor-alpha, and transforming growth factor-beta. J Clin Invest 1991, 88:1346-1353.

76. Wiggins RC, Njoku N, Sedor JR: Tissue factor production by cultured rat mesangial cells. Stimulation by TNF alpha and lipopolysaccharide. Kidney Int 1990, 37:1281-1285.

77. Schmidt C, Hocherl K, Schweda F, Bucher M: Proinflammatory cytokines cause down-regulation of renal chloride entry pathways during sepsis. Crit Care Med 2007, 35:2110-2119.

78. Schmidt C, Hocherl K, Bucher M: Regulation of renal glucose transporters during severe inflammation. Am J Physiol Renal Physiol 2007, 292:F804-F811.

79. Schmidt C, Hocherl K, Bucher M: Cytokine-mediated regulation of urea transporters during experimental endotoxemia. Am J Physiol Renal Physiol 2007, 292:F1479-F1489.

80. Schmidt C, Hocherl K, Schweda F, Kurtz A, Bucher M: Regulation of renal sodium transporters during severe inflammation. J Am Soc Nephro/ 2007, 18:1072-1083.

81. Wang Y, Moser AH, Shigenaga JK, Grunfeld C, Feingold KR: Downregulation of liver $\mathrm{X}$ receptor-alpha in mouse kidney and HK-2 proximal tubular cells by LPS and cytokines. J Lipid Res 2005, 46:2377-2387.

82. Khovidhunkit W, Kim MS, Memon RA, Shigenaga JK, Moser AH, Feingold KR, Grunfeld C: Effects of infection and inflammation on lipid and lipoprotein metabolism: mechanisms and consequences to the host. J Lipid Res 2004, 45:1169-1196.

83. Kawai T, Akira S: Toll-like receptor and RIG-I-like receptor signaling. Ann N Y Acad Sci 2008, 1143:1-20.

84. Meylan E, Tschopp J, Karin M: Intracellular pattern recognition receptors in the host response. Nature 2006, 442:39-44.

85. Dinarello CA: Biologic basis for interleukin-1 in disease. Blood 1996, 87:2095-2147

86. Tesch GH, Yang N, Yu H, Lan HY, Foti R, Chadban SJ, Atkins RC, NikolicPaterson DJ: Intrinsic renal cells are the major source of interleukin-1 beta synthesis in normal and diseased rat kidney. Nephrol Dial Transplant 1997, 12:1109-1115

87. Luo DD, Fielding C, Phillips A, Fraser D: Interleukin-1 beta regulates proximal tubular cell transforming growth factor beta-1 signalling. Nephrol Dial Transplant 2009, 24:2655-2665.

88. Pfeilschifter J, Huwiler A: Identification of ceramide targets in interleukinand tumor necrosis factor-alpha signaling in mesangial cells. Kidney Int Supp/ 1998, 67:S34-S39.

89. Abbott F, Ryan JJ, Ceska M, Matsushima K, Sarraf CE, Rees AJ: Interleukin-1 beta stimulates human mesangial cells to synthesize and release interleukins-6 and -8. Kidney Int 1991, 40:597-605.

90. Rovin BH, Yoshiumura T, Tan L: Cytokine-induced production of monocyte chemoattractant protein-1 by cultured human mesangial cells. J/mmuno 1992, 148:2148-2153.

91. Lee MJ, Yang CW, Jin DC, Chang YS, Bang BK, Kim YS: Bone morphogenetic protein-7 inhibits constitutive and interleukin-1 beta-induced monocyte chemoattractant protein-1 expression in human mesangial cells: role for JNK/AP-1 pathway. J Immunol 2003, 170:2557-2563.

92. Zoja C, Wang JM, Bettoni S, Sironi M, Renzi D, Chiaffarino F, Abboud HE, Van Damme J, Mantovani A, Remuzzi G, et al.: Interleukin-1 beta and tumor necrosis factor-alpha induce gene expression and production of leukocyte chemotactic factors, colony-stimulating factors, and interleukin-6 in human mesangial cells. Am J Pathol 1991, 138:991-1003.

93. Ikeda M, Ikeda U, Shimada K, Minota S, Kano S: Regulation of ICAM-1 expression by inflammatory cytokines in rat mesangial cells. Cytokine 1996, 8:109-114.

94. Guan Z, Buckman SY, Springer LD, Morrison AR: Both p38alpha(MAPK) and JNK/SAPK pathways are important for induction of nitric-oxide synthase by interleukin-1 beta in rat glomerular mesangial cells. J Biol Chem 1999, 274:36200-36206

95. Kihara M, Yabana M, Toya Y, Kobayashi S, Fujita T, Iwamoto T, Ishigami T, Umemura S: Angiotensin II inhibits interleukin-1 beta-induced nitric oxide production in cultured rat mesangial cells. Kidney Int 1999, 55:1277-1283.

96. Tateyama F, Yamabe H, Osawa H, Kaizuka M, Shirato K, Okumura K: Interleukin-1beta is an autocrine growth factor of rat glomerular epithelial cells in culture. Nephrol Dial Transplant 2001, 16:1149-1155.

97. Lang D, Terstesse M, Dohle F, Bangen P, Banas B, Pauels HG, Heidenreich S: Protein kinase $C$ (PKC) dependent induction of tissue factor (TF) by mesangial cells in response to inflammatory mediators and release during apoptosis. Br J Pharmacol 2002, 137:1116-1124

98. Eberhardt W, Beck KF, Pfeilschifter J: Cytokine-induced expression of tPA is differentially modulated by NO and ROS in rat mesangial cells. Kidney Int 2002, 61:20-30.

99. Gadient RA, Patterson PH: Leukemia inhibitory factor, Interleukin 6, and other cytokines using the GP130 transducing receptor: roles in inflammation and injury. Stem Cells 1999, 17:127-137.

100. Jones SA, Horiuchi S, Topley N, Yamamoto N, Fuller GM: The soluble interleukin 6 receptor: mechanisms of production and implications in disease. FASEB J 2001, 15:43-58.

101. Yan SF, Tritto I, Pinsky D, Liao H, Huang J, Fuller G, Brett J, May L, Stern D: Induction of interleukin 6 (IL-6) by hypoxia in vascular cells. Central role of the binding site for nuclear factor-IL-6. J Bio/ Chem 1995, 270:1 1463-11471.

102. Sekiyama KD, Yoshiba M, Thomson AW: Circulating proinflammatory cytokines (IL-1 beta, TNF-alpha, and IL-6) and IL-1 receptor antagonist (IL-1Ra) in fulminant hepatic failure and acute hepatitis. Clin Exp Immunol 1994, 98:71-77.

103. MacGowan GA, Mann DL, Kormos RL, Feldman AM, Murali S: Circulating interleukin-6 in severe heart failure. Am J Cardiol 1997, 79:1128-1131.

104. Simmons EM, Himmelfarb J, Sezer MT, Chertow GM, Mehta RL, Paganini EP, Soroko S, Freedman S, Becker K, Spratt D, Shyr Y, Ikizler TA; PICARD Study Group: Plasma cytokine levels predict mortality in patients with acute renal failure. Kidney Int 2004, 65:1357-1365.

105. Patel NS, Chatterjee PK, Di Paola R, Mazzon E, Britti D, De Sarro A, Cuzzocrea S, Thiemermann C: Endogenous interleukin- 6 enhances the renal injury, dysfunction, and inflammation caused by ischemia/reperfusion. J Pharmacol Exp Ther 2005, 312:1170-1178.

106. Nechemia-Arbely Y, Barkan D, Pizov G, Shriki A, Rose-John S, Galun E, Axelrod JH: IL-6/IL-6R axis plays a critical role in acute kidney injury. J Am Soc Nephrol 2008, 19:1106-1115.

107. Kielar ML, John R, Bennett M, Richardson JA, Shelton JM, Chen L, Jeyarajah DR, Zhou XJ, Zhou H, Chiquett B, Nagami GT, Lu CY: Maladaptive role of IL-6 in ischemic acute renal failure. J Am Soc Nephrol 2005, 16:3315-3325.

108. Mitazaki S, Kato N, Suto M, Hiraiwa K, Abe S: Interleukin-6 deficiency accelerates cisplatin-induced acute renal failure but not systemic injury. Toxicology 2009, 265:115-121.

109. Liu Y, Tolbert EM, Sun AM, Dworkin LD: Primary structure of rat HGF receptor and induced expression in glomerular mesangial cells. Am J Physiol 1996, 271:F679-F688.

110. Liu Y, Tolbert EM, Lin L, Thursby MA, Sun AM, Nakamura T, Dworkin LD: Up-regulation of hepatocyte growth factor receptor: an amplification and targeting mechanism for hepatocyte growth factor action in acute renal failure. Kidney Int 1999, 55:442-453.

111. Homsi E, Ribeiro-Alves MA, Lopes de Faria JB, Dias EP: Interleukin-6 stimulates tubular regeneration in rats with glycerol-induced acute renal failure. Nephron 2002, 92:192-199.

112. Ruef C, Budde K, Lacy J, Northemann W, Baumann M, Sterzel RB, Coleman DL Interleukin 6 is an autocrine growth factor for mesangial cells. Kidney Int 1990, 38:249-257.

113. Horii Y, Muraguchi A, Iwano M, Matsuda T, Hirayama T, Yamada H, Fujii Y, Dohi $\mathrm{K}$, Ishikawa H, Ohmoto Y, et al:: Involvement of IL-6 in mesangial proliferative glomerulonephritis. J Immunol 1989, 143:3949-3955.

114. Ikeda M, Ikeda U, Ohara T, Kusano E, Kano S: Recombinant interleukin-6 inhibits the growth of rat mesangial cells in culture. Am J Pathol 1992 141:327-334.

115. Sharyo S, Kumagai K, Yokota-Ikeda N, Ito K, Ikeda M: Amelioration of renal ischemia-reperfusion injury by inhibition of IL-6 production in the poloxamer 407-induced mouse model of hyperlipidemia. J Pharmacol Sci 2009, 110:47-54

116. Mosser DM, Zhang X: Interleukin-10: new perspectives on an old cytokine. Immunol Rev 2008, 226:205-218.

117. Wattanathum A, Manocha S, Groshaus H, Russell JA, Walley KR: Interleukin-10 haplotype associated with increased mortality in critically ill patients with sepsis from pneumonia but not in patients with extrapulmonary sepsis. Chest 2005, 128:1690-1698.

118. Deng J, Kohda Y, Chiao H, Wang Y, Hu X, Hewitt SM, Miyaji T, McLeroy P Nibhanupudy B, Li S, Star RA: Interleukin-10 inhibits ischemic and cisplatininduced acute renal injury. Kidney Int 2001, 60:2118-2128.

119. Fouqueray B, Boutard V, Philippe C, Kornreich A, Marchant A, Perez J, Goldman M, Baud L: Mesangial cell-derived interleukin-10 modulates 
mesangial cell response to lipopolysaccharide. Am J Pathol 1995, 147:176-182.

120. Chadban SJ, Tesch GH, Foti R, Lan HY, Atkins RC, Nikolic-Paterson DJ: Interleukin-10 differentially modulates MHC class II expression by mesangial cells and macrophages in vitro and in vivo. Immunology 1998, 94:72-78.

121. Parry RG, Gillespie KM, Mathieson PW: Effects of type 2 cytokines on glomerular epithelial cells. Exp Nephrol 2001, 9:275-283

122. Kalechman Y, Sredni B, Weinstein T, Freidkin I, Tobar A, Albeck M, Gafter U: Production of the novel mesangial autocrine growth factors GDNF and IL-10 is regulated by the immunomodulator AS101. J Am Soc Nephrol 2003, 14:620-630.

123. Robertson TE, Nikolic-Paterson DJ, Hurst LA, Atkins RC, Chadban SJ: IL-10 induces mesangial cell proliferation via a PDGF-dependent mechanism. Clin Exp Immunol 2002, 130:241-244

124. Chadban SJ, Tesch GH, Foti R, Atkins RC, Nikolic-Paterson DJ: Interleukin-10 is a mesangial cell growth factor in vitro and in vivo. Lab Invest 1997, 76:619-627

125. Iglesias J, Marik PE, Levine JS: Elevated serum levels of the type I and type II receptors for tumor necrosis factor-alpha as predictive factors for ARF in patients with septic shock. Am J Kidney Dis 2003, 41:62-75.

126. Liu KD, Glidden DV, Eisner MD, Parsons PE, Ware LB, Wheeler A, Korpak A Thompson BT, Chertow GM, Matthay MA: Predictive and pathogenetic value of plasma biomarkers for acute kidney injury in patients with acute lung injury. Crit Care Med 2007, 35:2755-2761.

127. Choi DE, Jeong JY, Lim BJ, Na KR, Shin YT, Lee KW: Pretreatment with the tumor necrosis factor-a blocker etanercept attenuated ischemiareperfusion renal injury. Transplant Proc 2009, 41:3590-3596.

128. Duffield JS, Ware CF, Ryffel B, Savill J: Suppression by apoptotic cells defines tumor necrosis factor-mediated induction of glomerular mesangial cell apoptosis by activated macrophages. Am J Pathol 2001, 159:1397-1404.

129. Misaki T, Yamamoto T, Suzuki S, Fukasawa H, Togawa A, Ohashi N, Suzuki H, Fujigaki Y, Oda T, Uchida C, Kitagawa K, Hattori T, Kitagawa M, Hishida A: Decrease in tumor necrosis factor-alpha receptor-associated death domain results from ubiquitin-dependent degradation in obstructive renal injury in rats. Am J Pathol 2009, 175:74-83.

130. Meldrum KK, Misseri R, Metcalfe P, Dinarello CA, Hile KL, Meldrum DR: TNF-alpha neutralization ameliorates obstruction-induced renal fibrosis and dysfunction. Am J Physiol Regul Integr Comp Physiol 2007, 292:R1456-R1464.

131. Marshall JC: Such stuff as dreams are made on: mediator-directed therapy in sepsis. Nat Rev Drug Discov 2003, 2:391-405.

132. Brown Z, Strieter RM, Neild GH, Thompson RC, Kunkel SL, Westwick J: IL-1 receptor antagonist inhibits monocyte chemotactic peptide 1 generation by human mesangial cells. Kidney Int 1992, 42:95-101.

133. Yokoo T, Kitamura M: Gene transfer of interleukin-1 receptor antagonist into the renal glomerulus via a mesangial cell vector. Biochem Biophys Res Commun 1996, 226:883-888.

134. Lan HY, Nikolic-Paterson DJ, Mu W, Vannice JL, Atkins RC: Interleukin-1 receptor antagonist halts the progression of established crescentic glomerulonephritis in the rat. Kidney Int 1995, 47:1303-1309.

135. Nikolic-Paterson DJ, Lan HY, Hill PA, Vannice JL, Atkins RC: Suppression of experimental glomerulonephritis by the interleukin-1 receptor antagonist: inhibition of intercellular adhesion molecule-1 expression. J Am Soc Nephrol 1994, 4:1695-1700.

136. Tang WW, Feng L, Vannice JL, Wilson CB: Interleukin-1 receptor antagonist ameliorates experimental anti-glomerular basement membrane antibody-associated glomerulonephritis. J Clin Invest 1994, 93:273-279.

137. Lan HY, Nikolic-Paterson DJ, Zarama M, Vannice JL, Atkins RC: Suppression of experimental crescentic glomerulonephritis by the interleukin-1 receptor antagonist. Kidney Int 1993, 43:479-485.

138. Rusai K, Huang H, Sayed N, Strobl M, Roos M, Schmaderer C, Heemann U, Lutz $\mathrm{J}$ : Administration of interleukin-1 receptor antagonist ameliorates renal ischemia-reperfusion injury. Transpl Int 2008, 21:572-580.

139. Schmouder RL, Strieter RM, Wiggins RC, Chensue SW, Kunkel SL: In vitro and in vivo interleukin-8 production in human renal cortical epithelia. Kidney Int 1992, 41:191-198.

140. Huber TB, Reinhardt HC, Exner M, Burger JA, Kerjaschki D, Saleem MA Pavenstadt $\mathrm{H}$ : Expression of functional CCR and CXCR chemokine receptors in podocytes. J Immunol 2002, 168:6244-6252.

141. Kusner DJ, Luebbers EL, Nowinski RJ, Konieczkowski M, King CH, Sedor JR:
Cytokine- and LPS-induced synthesis of interleukin-8 from human mesangial cells. Kidney Int 1991, 39:1240-1248.

142. Brown Z, Strieter RM, Chensue SW, Ceska M, Lindley I, Neild GH, Kunkel SL, Westwick J: Cytokine-activated human mesangial cells generate the neutrophil chemoattractant, interleukin 8. Kidney Int 1991, 40:86-90.

143. Liu KD, Altmann C, Smits G, Krawczeski CD, Edelstein CL, Devarajan P, Faubel S: Serum interleukin- 6 and interleukin- 8 are early biomarkers of acute kidney injury and predict prolonged mechanical ventilation in children undergoing cardiac surgery: a case-control study. Crit Care 2009, 13:R104.

144. Liangos O, Kolyada A, Tighiouart H, Perianayagam MC, Wald R, Jaber BL: Interleukin-8 and acute kidney injury following cardiopulmonary bypass: a prospective cohort study. Nephron Clin Pract 2009, 113:c148-c154.

145. Tsai CY, Yu CL, Wu TH, Hsieh SC, Tsai YY: Proinflammatory cytokines enhance COX-1 gene expression in cultured rat glomerular mesangial cells. Int Immunopharmacol 2004, 4:47-56.

146. Garin EH, West L, Zheng W: Effect of interleukin-8 on glomerular sulfated compounds and albuminuria. Pediatr Nephrol 1997, 11:274-279.

147. Driscoll KE: Macrophage inflammatory proteins: biology and role in pulmonary inflammation. Exp Lung Res 1994, 20:473-490.

148. Shastry S, James LR: Homocysteine-induced macrophage inflammatory protein- 2 production by glomerular mesangial cells is mediated by $\mathrm{PI} 3$ kinase and p38 MAPK. J Inflamm (Lond) 2009, 6:27.

149. Walpen S, Beck KF, Schaefer L, Raslik I, Eberhardt W, Schaefer RM, Pfeilschifter $\mathrm{J}$ : Nitric oxide induces MIP-2 transcription in rat renal mesangial cells and in a rat model of glomerulonephritis. FASEB J 2001, 15:571-573.

150. Fujita T, Yamabe H, Shimada M, Murakami R, Kumasaka R, Nakamura N, Osawa $\mathrm{H}$, Okumura K: Thrombin enhances the production of monocyte chemoattractant protein-1 and macrophage inflammatory protein-2 in cultured rat glomerular epithelial cells. Nephrol Dial Transplant 2008 23:3412-3417

151. Luo Y, Lloyd C, Gutierrez-Ramos JC, Dorf ME: Chemokine amplification in mesangial cells. J Immunol 1999, 163:3985-3992.

152. Feng $L, X i a$ Y, Yoshimura T, Wilson CB: Modulation of neutrophil influx in glomerulonephritis in the rat with anti-macrophage inflammatory protein-2 (MIP-2) antibody. J Clin Invest 1995, 95:1009-1017.

153. Roche JK, Keepers TR, Gross LK, Seaner RM, Obrig TG: CXCL1/KC and CXCL2/ MIP-2 are critical effectors and potential targets for therapy of Escherichia coli 0157:H7-associated renal inflammation. Am J Pathol 2007, 170:526-537.

154. Ueland JM, Gwira J, Liu ZX, Cantley LG: The chemokine KC regulates HGF-stimulated epithelial cell morphogenesis. Am J Physiol Renal Physiol 2004, 286:F581-F589

155. Viedt C, Dechend R, Fei J, Hansch GM, Kreuzer J, Orth SR: MCP-1 induces inflammatory activation of human tubular epithelial cells: involvement of the transcription factors, nuclear factor-kappaB and activating protein-1. J Am Soc Nephrol 2002, 13:1534-1547.

156. Hasegawa H, Kohno M, Sasaki M, Inoue A, Ito MR, Terada M, Hieshima K, Maruyama H, Miyazaki J, Yoshie O, Nose M, Fujita S: Antagonist of monocyte chemoattractant protein 1 ameliorates the initiation and progression of lupus nephritis and renal vasculitis in MRL/lpr mice. Arthritis Rheum 2003, 48:2555-2566

157. Tesch GH, Schwarting A, Kinoshita K, Lan HY, Rollins BJ, Kelley VR: Monocyte chemoattractant protein-1 promotes macrophage-mediated tubular injury, but not glomerular injury, in nephrotoxic serum nephritis. J Clin Invest 1999, 103:73-80.

158. Ninichuk V, Clauss S, Kulkarni O, Schmid H, Segerer S, Radomska E, Eulberg D, Buchner K, Selve N, Klussmann S, Anders HJ: Late onset of C $\mathrm{Cl} 2$ blockade with the Spiegelmer mNOX-E36-3'PEG prevents glomerulosclerosis and improves glomerular filtration rate in $\mathrm{db} / \mathrm{db}$ mice. Am J Patho/ 2008, 172:628-637.

159. Clauss S, Gross O, Kulkarni O, vila-Ferrufino A, Radomska E, Segerer S, Eulberg D, Klussmann S, Anders HJ: Ccl2/Mcp-1 blockade reduces glomerular and interstitial macrophages but does not ameliorate renal pathology in collagen4A3-deficient mice with autosomal recessive Alport nephropathy. J Pathol 2009, 218:40-47.

160. Wenzel U, Schneider A, Valente AJ, Abboud HE, Thaiss F, Helmchen UM, Stahl RA: Monocyte chemoattractant protein-1 mediates monocyte/ macrophage influx in anti-thymocyte antibody-induced glomerulonephritis. Kidney Int 1997, 51:770-776.

161. Tang WW, Qi M, Warren JS: Monocyte chemoattractant protein 1 mediates glomerular macrophage infiltration in anti-GBM Ab GN. Kidney Int 1996, 50:665-671. 
162. Giunti S, Pinach S, Arnaldi L, Viberti G, Perin PC, Camussi G, Gruden G: The MCP-1/CCR2 system has direct proinflammatory effects in human mesangial cells. Kidney Int 2006, 69:856-863.

163. Burt D, Salvidio G, Tarabra E, Barutta F, Pinach S, Dentelli P, Camussi G, Perin PC, Gruden G: The monocyte chemoattractant protein-1/cognate CC chemokine receptor 2 system affects cell motility in cultured human podocytes. Am J Pathol 2007, 171:1789-1799.

164. Shimizu H, Maruyama S, Yuzawa Y, Kato T, Miki Y, Suzuki S, Sato W, Morita Y, Maruyama H, Egashira K, Matsuo S: Anti-monocyte chemoattractant protein-1 gene therapy attenuates renal injury induced by proteinoverload proteinuria. J Am Soc Nephrol 2003, 14:1496-1505.

165. Lloyd CM, Minto AW, Dorf ME, Proudfoot A, Wells TN, Salant DJ, GutierrezRamos JC: RANTES and monocyte chemoattractant protein-1 (MCP-1) play an important role in the inflammatory phase of crescentic nephritis, but only MCP-1 is involved in crescent formation and interstitial fibrosis. J Exp Med 1997, 185:1371-1380.

166. Schneider A, Panzer U, Zahner G, Wenzel U, Wolf G, Thaiss F, Helmchen U, Stahl RA: Monocyte chemoattractant protein-1 mediates collagen deposition in experimental glomerulonephritis by transforming growth factor-beta. Kidney Int 1999, 56:135-144.

167. Giunti S, Tesch GH, Pinach S, Burt DJ, Cooper ME, Cavallo-Perin P, Camussi G, Gruden G: Monocyte chemoattractant protein-1 has prosclerotic effects both in a mouse model of experimental diabetes and in vitro in human mesangial cells. Diabetologia 2008, 51:198-207.

168. Tarabra E, Giunti S, Barutta F, Salvidio G, Burt D, Deferrari G, Gambino R, Vergola D, Pinach S, Perin PC, Camussi G, Gruden G: Effect of the monocyte chemoattractant protein-1/CC chemokine receptor 2 system on nephrin expression in streptozotocin-treated mice and human cultured podocytes. Diabetes 2009, 58:2109-2118.

169. Kitching AR, Kong YZ, Huang XR, Davenport P, Edgtton KL, Carmeliet $P$, Holdsworth SR, Tipping PG: Plasminogen activator inhibitor-1 is a significant determinant of renal injury in experimental crescentic glomerulonephritis. J Am Soc Nephrol 2003, 14:1487-1495.

170. Seo JY, Park J, Yu MR, Kim YS, Ha H, Lee HB: Positive feedback loop between plasminogen activator inhibitor-1 and transforming growth factor-beta1 during renal fibrosis in diabetes. Am J Nephrol 2009, 30:481-490.

171. Hertig A, Berrou J, Allory Y, Breton L, Commo F, Costa De Beauregard MA, Carmeliet $\mathrm{P}$, Rondeau E: Type 1 plasminogen activator inhibitor deficiency aggravates the course of experimental glomerulonephritis through overactivation of transforming growth factor beta. FASEB J 2003, 17:1904-1906.

172. Matsuo S, Lopez-Guisa JM, Cai X, Okamura DM, Alpers CE, Bumgarner RE, Peters MA, Zhang G, Eddy AA: Multifunctionality of PAl-1 in fibrogenesis: evidence from obstructive nephropathy in PAl-1-overexpressing mice. Kidney Int 2005, 67:2221-2238

173. Nicholas SB, Aguiniga E, Ren Y, Kim J, Wong J, Govindarajan N, Noda M, Wang W, Kawano Y, Collins A, Hsueh WA: Plasminogen activator inhibitor-1 deficiency retards diabetic nephropathy. Kidney Int 2005, 67:1297-1307.

174. Hu K, Mars WM, Liu Y: Novel actions of tissue-type plasminogen activator in chronic kidney disease. Front Biosci 2008, 13:5174-5186.

175. Roelofs JJ, Rouschop KM, Leemans JC, Claessen N, de Boer AM, Frederiks WM, Lijnen HR, Weening JJ, Florquin S: Tissue-type plasminogen activator modulates inflammatory responses and renal function in ischemia reperfusion injury. J Am Soc Nephrol 2006, 17:131-140.

176. Yang J, Shultz RW, Mars WM, Wegner RE, Li Y, Dai C, Nejak K, Liu Y: Disruption of tissue-type plasminogen activator gene in mice reduces renal interstitial fibrosis in obstructive nephropathy. J Clin Invest 2002. 110:1525-1538

177. Haraguchi M, Border WA, Huang Y, Noble NA: t-PA promotes glomerular plasmin generation and matrix degradation in experimental glomerulonephritis. Kidney Int 2001, 59:2146-2155.

178. Kitching AR, Holdsworth SR, Ploplis VA, Plow EF, Collen D, Carmeliet P, Tipping PG: Plasminogen and plasminogen activators protect against renal injury in crescentic glomerulonephritis. J Exp Med 1997, 185:963-968.

179. Gupta A, Williams MD, Macias WL, Molitoris BA, Grinnell BW: Activated protein $C$ and acute kidney injury: Selective targeting of PAR-1. Curr Drug Targets 2009, 10:1212-1226.

180. Mizutani A, Okajima K, Uchiba M, Noguchi T: Activated protein C reduces ischemia/reperfusion-induced renal injury in rats by inhibiting leukocyte activation. Blood 2000, 95:3781-3787.

181. Park SW, Chen SW, Kim M, D'Agati VD, Lee HT: Human activated protein C attenuates both hepatic and renal injury caused by hepatic ischemia and reperfusion injury in mice. Kidney Int 2009, 76:739-750.

182. Gupta A, Gerlitz B, Richardson MA, Bull C, Berg DT, Syed S, Galbreath EJ, Swanson BA, Jones BE, Grinnell BW: Distinct functions of activated protein C differentially attenuate acute kidney injury. J Am Soc Nephrol 2009 20:267-277.

183. Gupta A, Berg DT, Gerlitz B, Sharma GR, Syed S, Richardson MA, Sandusky G, Heuer JG, Galbreath EJ, Grinnell BW: Role of protein C in renal dysfunction after polymicrobial sepsis. J Am Soc Nephrol 2007, 18:860-867.

184. Gupta A, Rhodes GJ, Berg DT, Gerlitz B, Molitoris BA, Grinnell BW: Activated protein $C$ ameliorates LPS-induced acute kidney injury and downregulates renal INOS and angiotensin 2. Am J Physiol Renal Physiol 2007, 293:F245-F254

185. Isermann B, Vinnikov IA, Madhusudhan T, Herzog S, Kashif M, Blautzik J, Corat MA, Zeier M, Blessing E, Oh J, Gerlitz B, Berg DT, Grinnell BW, Chavakis T, Esmon CT, Weiler H, Bierhaus A, Nawroth PP: Activated protein C protects against diabetic nephropathy by inhibiting endothelial and podocyte apoptosis. Nat Med 2007, 13:1349-1358.

186. Eremina V, Baelde HJ, Quaggin SE: Role of the VEGF--a signaling pathway in the glomerulus: evidence for crosstalk between components of the glomerular filtration barrier. Nephron Physiol 2007, 106:32-37.

187. Schrijvers BF, Flyvbjerg A, De Vriese AS: The role of vascular endothelial growth factor (VEGF) in renal pathophysiology. Kidney Int 2004, 65:2003-2017.

188. Shimizu A, Masuda Y, Mori T, Kitamura H, Ishizaki M, Sugisaki Y, Fukuda Y: Vascular endothelial growth factor 165 resolves glomerular inflammation and accelerates glomerular capillary repair in rat anti-glomerular basement membrane glomerulonephritis. J Am Soc Nephrol 2004, 15:2655-2665.

189. Suga S, Kim YG, Joly A, Puchacz E, Kang DH, Jefferson JA, Abraham JA, Hughes J, Johnson RJ, Schreiner GF: Vascular endothelial growth factor (VEGF121) protects rats from renal infarction in thrombotic microangiopathy. Kidney Int 2001, 60:1297-1308.

190. Muller-Deile J, Worthmann K, Saleem M, Tossidou I, Haller H, Schiffer M: The balance of autocrine VEGF-A and VEGF-C determines podocyte survival. Am J Physiol Renal Physiol 2009, 297:F1656-F1667.

191. Ostendorf T, Kunter U, Eitner F, Loos A, Regele H, Kerjaschki D, Henninger DD, Janjic N, Floege J: VEGF(165) mediates glomerular endothelial repair. J Clin Invest 1999, 104:913-923.

192. Kanellis J, Fraser S, Katerelos M, Power DA: Vascular endothelial growth factor is a survival factor for renal tubular epithelial cells. Am J Physiol Renal Physiol 2000, 278:F905-F915.

193. Feliers D, Chen X, Akis N, Choudhury GG, Madaio M, Kasinath BS: VEGF regulation of endothelial nitric oxide synthase in glomerular endothelial cells. Kidney Int 2005, 68:1648-1659.

194. Kang DH, Hughes J, Mazzali M, Schreiner GF, Johnson RJ: Impaired angiogenesis in the remnant kidney model: II. Vascular endothelial growth factor administration reduces renal fibrosis and stabilizes renal function. J Am Soc Nephrol 2001, 12:1448-1457.

195. Satchell SC, Anderson KL, Mathieson PW: Angiopoietin 1 and vascular endothelial growth factor modulate human glomerular endothelial cell barrier properties. J Am Soc Nephrol 2004, 15:566-574.

196. Chen J, Braet F, Brodsky S, Weinstein T, Romanov V, Noiri E, Goligorsky MS: VEGF-induced mobilization of caveolae and increase in permeability of endothelial cells. Am J Physiol Cell Physiol 2002, 282:C1053-C1063.

197. Schneider P, Holler N, Bodmer JL, Hahne M, Frei K, Fontana A, Tschopp J: Conversion of membrane-bound Fas(CD95) ligand to its soluble form is associated with downregulation of its proapoptotic activity and loss of liver toxicity. J Exp Med 1998, 187:1205-1213.

198. Suda T, Hashimoto H, Tanaka M, Ochi T, Nagata S: Membrane Fas ligand kills human peripheral blood T lymphocytes, and soluble Fas ligand blocks the killing. J Exp Med 1997, 186:2045-2050.

199. Knaus WA, Draper EA, Wagner DP, Zimmerman JE: Prognosis in acute organsystem failure. Ann Surg 1985, 202:685-693.

200. Gurkan OU, O'Donnell C, Brower R, Ruckdeschel E, Becker PM: Differential effects of mechanical ventilatory strategy on lung injury and systemic organ inflammation in mice. Am J Physiol Lung Cell Mol Physiol 2003, 285:L710-L718

201. Hegeman MA, Hennus MP, Heijnen CJ, Specht PA, Lachmann B, Jansen NJ, van Vught AJ, Cobelens PM: Ventilator-induced endothelial activation and inflammation in the lung and distal organs. Crit Care 2009, 13:R182. 
202. Chiumello D, Pristine G, Slutsky AS: Mechanical ventilation affects local and systemic cytokines in an animal model of acute respiratory distress syndrome. Am J Respir Crit Care Med 1999, 160:109-116.

203. Guery BP, Welsh DA, Viget NB, Robriquet L, Fialdes P, Mason CM, Beaucaire G Bagby GJ, Neviere R: Ventilation-induced lung injury is associated with an increase in gut permeability. Shock 2003, 19:559-563.

204. Haitsma JJ, Uhlig S, Goggel R, Verbrugge SJ, Lachmann U, Lachmann B: Ventilator-induced lung injury leads to loss of alveolar and systemic compartmentalization of tumor necrosis factor-alpha. Intensive Care Med 2000, 26:1515-1522.

205. Haitsma JJ, Uhlig S, Lachmann U, Verbrugge SJ, Poelma DL, Lachmann B: Exogenous surfactant reduces ventilator-induced decompartmentalization of tumor necrosis factor alpha in absence of positive end-expiratory pressure. Intensive Care Med 2002, 28:1131-1137.

206. Haitsma JJ, Uhlig S, Verbrugge SJ, Goggel R, Poelma DL, Lachmann B: Injurious ventilation strategies cause systemic release of IL-6 and MIP-2 in rats in vivo. Clin Physiol Funct Imaging 2003, 23:349-353.

207. Herrera MT, Toledo C, Valladares F, Muros M, Diaz-Flores L, Flores C, Villar J: Positive end-expiratory pressure modulates local and systemic inflammatory responses in a sepsis-induced lung injury model. Intensive Care Med 2003, 29:1345-1353.

208. Murphy DB, Cregg N, Tremblay L, Engelberts D, Laffey JG, Slutsky AS, Romaschin A, Kavanagh BP: Adverse ventilatory strategy causes pulmonary-to-systemic translocation of endotoxin. Am J Respir Crit Care Med 2000, 162:27-33

209. Oliveira-Junior IS, Pinheiro BV, Silva ID, Salomao R, Zollner RL, Beppu OS: Pentoxifylline decreases tumor necrosis factor and interleukin-1 during high tidal volume. Braz J Med Biol Res 2003, 36:1349-1357.

210. Schortgen F, Bouadma L, Joly-Guillou ML, Ricard JD, Dreyfuss D, Saumon G: Infectious and inflammatory dissemination are affected by ventilation strategy in rats with unilateral pneumonia. Intensive Care Med 2004 30:693-701

211. Vreugdenhil HA, Heijnen CJ, Plotz FB, Zijlstra J, Jansen NJ, Haitsma JJ, Lachmann B, van Vught AJ: Mechanical ventilation of healthy rats suppresses peripheral immune function. Eur Respir J 2004, 23:122-128.

212. Wolthuis EK, Vlaar AP, Choi G, Roelofs JJ, Juffermans NP, Schultz MJ: Mechanical ventilation using non-injurious ventilation settings causes lung injury in the absence of pre-existing lung injury in healthy mice. Crit Care 2009, 13:R1-R11.

213. Masuda Y, Shimizu A, Mori T, Ishiwata T, Kitamura H, Ohashi R, Ishizaki M, Asano G, Sugisaki Y, Yamanaka N: Vascular endothelial growth factor enhances glomerular capillary repair and accelerates resolution of experimentally induced glomerulonephritis. Am J Pathol 2001, 159:599-608.

214. Hakroush S, Moeller MJ, Theilig F, Kaissling B, Sijmonsma TP, Jugold M, Akeson AL, Traykova-Brauch M, Hosser H, Hähnel B, Gröne HJ, Koesters R, Kriz W: Effects of increased renal tubular vascular endothelial growth factor (VEGF) on fibrosis, cyst formation, and glomerular disease. Am J Pathol 2009, 175:1883-1895.

215. Leonard EC, Friedrich JL, Basile DP: VEGF-121 preserves renal microvessel structure and ameliorates secondary renal disease following acute kidney injury. Am J Physiol Renal Physiol 2008, 295:F1648-F1657.

216. De Vriese AS, Tilton RG, Elger M, Stephan CC, Kriz W, Lameire NH: Antibodies against vascular endothelial growth factor improve early renal dysfunction in experimental diabetes. J Am Soc Nephrol 2001, 12:993-1000.

217. Kim YG, Suga SI, Kang DH, Jefferson JA, Mazzali M, Gordon KL, Matsui K, Breiteneder-Geleff S, Shankland SJ, Hughes J, Kerjaschki D, Schreiner GF, Johnson RJ: Vascular endothelial growth factor accelerates renal recovery in experimental thrombotic microangiopathy. Kidney Int 2000, 58:2390-2399.

218. Li ZD, Bork JP, Krueger B, Patsenker E, Schulze-Krebs A, Hahn EG, Schuppan D: VEGF induces proliferation, migration, and TGF-beta1 expression in mouse glomerular endothelial cells via mitogen-activated protein kinase and phosphatidylinositol 3-kinase. Biochem Biophys Res Commun 2005 334:1049-1060.

219. Veron D, Reidy KJ, Bertuccio C, Teichman J, Villegas G, Jimenez J, Shen W, Kopp JB, Thomas DB, Tufro A: Overexpression of VEGF-A in podocytes of adult mice causes glomerular disease. Kidney Int 2010, 77:989-999.

220. Liu E, Morimoto M, Kitajima S, Koike T, Yu Y, Shiiki H, Nagata M, Watanabe T, Fan J: Increased expression of vascular endothelial growth factor in kidney leads to progressive impairment of glomerular functions. J Am Soc Nephrol 2007, 18:2094-2104.

221. Hara A, Wada T, Furuichi K, Sakai N, Kawachi H, Shimizu F, Shibuya M, Matsushima K, Yokoyama H, Egashira K, Kaneko S: Blockade of VEGF accelerates proteinuria, via decrease in nephrin expression in rat crescentic glomerulonephritis. Kidney Int 2006, 69:1986-1995.

doi:10.1186/cc10282

Cite this article as: Kuiper JW, et al.: Bench-to-bedside review: Ventilationinduced renal injury through systemic mediator release - just theory or a causal relationship? Critical Care 2011, 15:228 